\title{
A Scoping Review of Health Promotion in the Nursing Home Setting
}

\author{
Tannys Helfer ${ }^{1}$, Kathrin Sommerhalder ${ }^{1}$, Jos M.G.A. Schols², Sabine Hahn ${ }^{1}$
}

\begin{abstract}
Background Nursing homes in many countries continue to follow a traditional medical model of care. This study explored health promotion approaches in the nursing home setting, partly in order to move away from a medical model and to improve the well-being of residents and staff.

Method A scoping study was conducted to review the scientific literature. The Integrated Model of Population Health and Health Promotion was adapted for utilization with the literature analysis.

Results A total of 64 publications met the inclusion criteria and were analysed. Five main approaches were shown to have applied health promotion in nursing homes, although gaps were present in the usage of systematically applied health promotion. Conclusion A variety of approaches do exist for the nursing home setting which apply health promotion; however, their usage is fragmented. This study revealed that a framework designed to support nursing homes in the systematic usage of health promotion, could improve the well-being for both residents and staff.
\end{abstract}

\section{About the AUTHORS}

1 Bern University of Applied Sciences, Department of Health Professions, Applied Research \& Development in Nursing, Bern, Switzerland 2 Maastricht University, Caphri - School for Public Health and Primary Care, Department of Family Medicine and Department of Health Services Research, Maastricht, Netherlands

Contact: Tannys Helfer tannys.helfer@bfh.ch

\section{Background}

Globally, the population is aging at a rapid rate. According to Katz, "In 2000 there were 600 million older persons, triple the number of just 50 years earlier. By 2050 there will be 2 billion older adults" (1). Therefore, the well-being of older persons, including those residing in nursing homes (NHs), has become an common aim in health care systems of many countries, (2). Nevertheless, NHs in many westernized countries continue to follow or adapt a traditional medical model of care, which typically focuses on patient regimes, treating illness. and top-down decision making. NHs dominated by a medical model are more likely at risk of compromising basic human rights and liberties, such as the resident's entitlement to independence, participation, care, self-fulfillment, and dignity (3).

The NH setting is complex and requires skilled and engaged workers. $\mathrm{NH}$ residents are often affected by multiple health challenges, particularly chronic diseases and/or cognitive difficulties, which frequently include dementia (4). In particular, well educated and experienced registered nurses and $\mathrm{NH}$ managers play a crucial role in the assurance of quality and safety for both the residents and other staff groups. Emphasis on the importance of their leadership qualities is increasing, as this affects the workplace environment and the health of nursing staff (5).

New and complementary approaches are necessary which meet the needs of both the residents and the nursing staff. Health promotion (HP), could potentially offer such an approach and thereby assist in improving the well-being of the $\mathrm{NH}$ residents and nursing staff. There are fundamental, key concepts which guide the planning and implementation of HP. These include the Ottawa Charter, which recommends the following HP action strategies: developing personal skills, creating supportive environments, strengthening community action, reorienting health services and building healthy public policy (6). Also included are the Social Determinants of Health, which are the social factors that affect peoples' health. According to Harris \& Grootjans (7), the most important external influencing factors affecting the health of older persons in the $\mathrm{NH}$ environment include governance, the physical environment 


\section{Research and Best Practice}

as well as the social environment. The Ottawa Charter strategies are intended to target their actions on the Social Determinants of Health.

The World Health Organization (WHO) has specifically put forth a framework to assist in broadly addressing the issue of a growing aging population. As part of their framework, the WHO proposes the following Active Aging Determinants: culture, behaviour, personal factors, physical environment, social environment, economic characteristics as well as health and social care (8). Nevertheless, they are not entirely suitable for those residing in NHs. To address this deficit, it is proposed that meaningful leisure and participation be added to these already existing Active Aging Determinants (9).

In order to implement complementary approaches such as HP in the NH setting, it is first necessary to determine how it has been already applied. To the authors' knowledge, no such overview exists, especially one examining which HP strategies have been integrated in NHs, which improve both the well-being of $\mathrm{NH}$ residents and the work environment for staff. Therefore, the first aim of this study is to provide this overview from the literature, describing how $\mathrm{HP}$ has been applied in the NH setting for both residents and staff. The second aim is to examine the extent in which HP has systematically been applied in the NH setting. This knowledge will reveal where progress has been made and where gaps still exist. In order to achieve these aims, the research questions to be examined are:

- Which approaches to HP in nursing homes are present in the literature (What has been done)?

- To what extent were the following key HP concepts systematically utilized: the Ottawa Charter action strategies, the Social Determinants of Health, and the active aging determinants (pertinent to NH residents)?

\section{Methods}

\section{Scoping review design overview}

To answer the the research questions, we have chosen a scoping review design because there appeared to be a paucity of literature which focused on current HP strategies and principles applied to the NH setting. Scoping studies are ideal to review complex areas (10) and to examine and summarize the extent, the range, the nature of research activity, and the findings (11). They offer an overview of the evidence, regardless of its quality, as they aim to map out and explore what evidence is available rather than only seek the best evidence. Therefore, they are very suitable for addressing the exploratory nature of our research questions (12). As a scoping review was conducted, the methodological quality of the included publications was not assessed. According to Arksey and O'Malley (10), the following six stage methodological framework should guide scoping studies: (1) identify the research question; (2) search for relevant publications; (3) select publications; (4) chart the data; (5) collate, summarize, and report the results; (6) consult with stakeholders to inform or validate study findings (optional). For the purpose of this study we omitted step 6 , as our intention was to undertake an initial exploration of the literature.

\section{Data collection and analysis}

In alignment with step 2 of the scoping review methodology, relevant publications in accordance to our the research questions were searched for in PubMed, Cumulative Index to Nursing and Allied Health Literature (CINAHL), and Web of Science databases. The inclusion criteria (see Table 1) consisted of publications which focused on HP in the NH setting from 2003 to 2020. This early time frame was chosen, because 2003 was when research focusing on assessing the living conditions for $\mathrm{NH}$ residents started to become more evident in the literature. Publications did not have to be labelled as utilizing HP; however, they did have to demonstrate usage of key HP strategies or concepts. MeSH terms and single text terms were combined for the literature search in the databases (see Table 1).

\section{Selection of publications}

In accordance with step 3 of the scoping review methodology, relevant publications were selected (see Prisma Diagram - Figure 1 (13)) . One author searched for and included all titles and abstracts which were congruent with the inclusion criteria. The total number of hits per database were as follows: Pub Med (267), CINAHL (168) and Web of Science (264). A total of 287 abstracts were identified for further analysis.

In the next step, these abstracts were reviewed by two authors. Upon analysis, 150 publications were excluded due to a clear lack of fit of the abstract with the inclusion criteria. In total, 137 publications remained and were retrieved to undergo further analysis of the full text (with the same authors as the abstract reviews). After this last step of analysing the full text, 64 publications remained and were included in this scoping review. The other 73 publications were excluded either because their main focus was not on the NH setting, or because upon further analysis, a lack of fit with the inclusion criteria became apparent. 


\section{Research and Best Practice}

Table 1: Inclusion criteria and literature search terms

\begin{tabular}{ll}
\hline Inclusion criteria & Description \\
\hline Time frame and journals & Between 2003 and 2020 in scientific journals \\
\hline Language & Published in English or German (with English abstracts) \\
\hline Type of publication & - Focused on health promotion in the NH setting \\
& - All types of research designs, study protocols and systematic reviews (to be analysed at the summary level) \\
& - Expert opinions \\
& - WHO reports, national and international recommendations which apply to both HP and older persons.
\end{tabular}

\section{Literature Search Terms}

\section{RESIDENT ORIENTATED SEARCH}

"health promotion" (MeSH), "Nursing Homes" (MeSH)

AND

were used alone or in combination with the following single text terms: residents, care homes, framework, strategy, implementation, philosophy, policy, national policy, framework, health promoting, long term care, resident centered care, elderly, ecological model, settings approach, social ecological approach, salutogenesis model, or social determinants of health.

\section{STAFF ORIENTATED SEARCH}

"Nursing Homes" (MeSH), "Health Promotion" (MeSH), Staff (single term)

AND

these three main search terms were used alone or in combination with the following single text terms: workplace, workplace health, workplace health promotion, workplace health promotion program, model, strategy, framework, program, setting, person centered workplace, worksite interventions, and participatory staff workplace health.

Grey literature, such as international recommendations, was concurrently found during the database searches, due to the broad focus of the literature search methodology.

\section{Data Extraction and Documentation in Accordance to Structured Protocol}

In order to chart the data as per step 4 of the scoping review methodology, key information from each publication concerning the two research questions was individually extracted and documented. This was un-
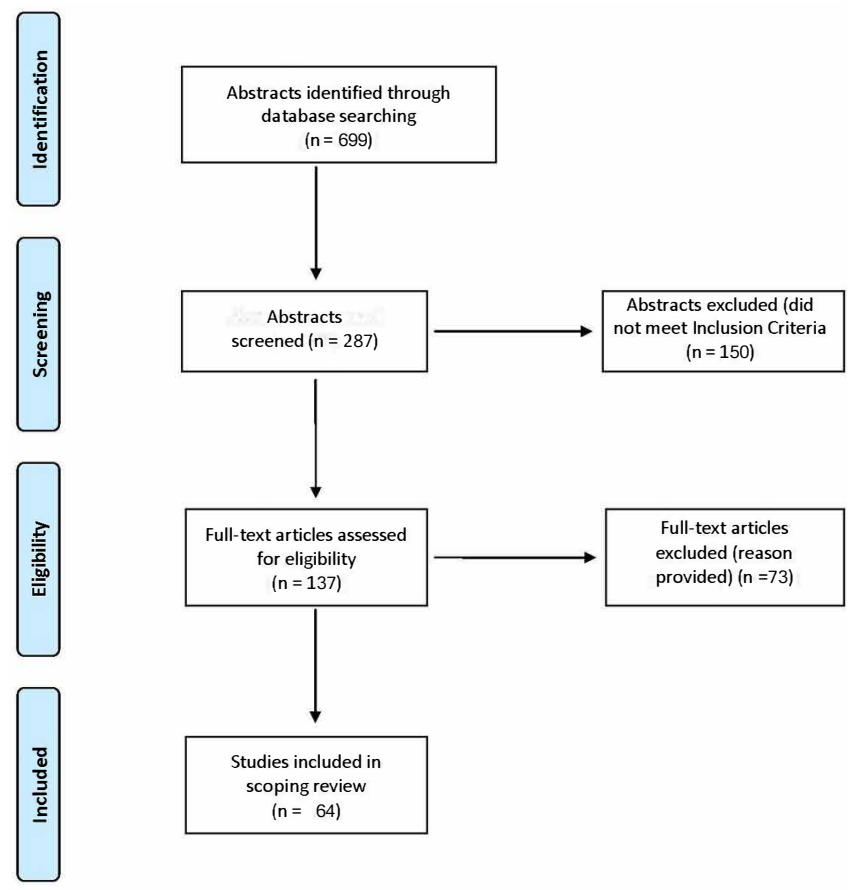

Figure 1. Prisma Flow Diagram. Diagram obtained from (13). dertaken according to a structured protocol (see Figure 2), which is based upon an internationally recognized tool in HP practice. This tool, the Integrated Model of Population Health and Health Promotion (14), is designed for assisting with program development and implementation among the general population. It includes the following three aspects: the Ottawa Charter action strategies, the Determinants of Health and the Population Health Levels. The Population Health Levels refer to with whom or at which level actions are focused upon: individual, family, community, sector/ system and/or society.

For the purposes of this study, the Integrated Model of Population Health and Health Promotion $(13 ; 14)$ was adapted a-priori to data collection. The Ottawa Charter and the population health levels were not altered; however, we replaced the Determinants of Health with the Social Determinants of Health, as the social environment in which $\mathrm{NH}$ residents live in determines their health more than the Determinants of Health. As Social Determinants of Health specific to NH residents are, to the authors' knowledge, not available in the literature, we based them upon what $\mathrm{NH}$ residents reported as being the most important external influencing factors to their health in the $\mathrm{NH}$ environment: governance, physical environment, social environment (7). The active aging determinants were also included as a Social Determinant of Health due to their influence on 


\begin{tabular}{|c|c|c|c|c|c|}
\hline & \multicolumn{5}{|c|}{ Population Health Levels } \\
\hline & Individual & Family & *Nursing Home & Sector/System & Societal \\
\hline Develop Personal Skills & $x$ & $x$ & $x$ & $x$ & $x$ \\
\hline Create a Supportive Environment & $x$ & $x$ & $x$ & $x$ & $\mathrm{x}$ \\
\hline Strengthen Community Action & $x$ & $x$ & $x$ & $x$ & $x$ \\
\hline Build Healthy Public Policy & $x$ & $x$ & $x$ & $x$ & $x$ \\
\hline Re-orient Health Services & $x$ & $x$ & $x$ & $x$ & $x$ \\
\hline
\end{tabular}

* For the purposes of this paper, $\mathrm{NH}$ is utilized instead of Community Level (as is utilized in the Integrated Model of Population Health and Health Promotion)

Figure 2. The Adapted Integrated Model of Population Health and Health Promotion. Adapted by the authors. Based on (14).

well-being for older persons $(8 ; 9)$. No pilot testing of the protocol was undertaken due to the exploratory nature of this study.

One author completed data extraction in accordance to the research questions, utilizing the structured protocol (see Figure 2). Another author was consulted when a second opinion was deemed necessary. First, it was determined which Ottawa Charter action strategies were utilized. Second, it was ascertained which population health levels within the Ottawa Charter action strategies were focused upon. Third, it was determined which Social Determinants of Health each publication was centered upon. The synthesis of these assessments revealed to what extent (no usage to strong usage) HP had been applied in each of the publications. In accordance with optimal HP practice, an approach is considered to be more and comprehensive when it targets multiple Ottawa Charter action strategies at as many levels as possible, and when it focuses its actions on the Social Determinants of Health.

\section{Results}

Due to the exploratory nature of this study and the methodology of a scoping review, the focus of the included 64 publications was broad. Inclusion of this wide range of publications was undertaken in order to gain an overview of how and the extent in which HP has been applied in the NH setting for both residents and staff. However, many publications included in this study were based upon expert opinions or were discussion papers, and fewer publications utilized rigorous methodologies. The publications in this study were not examined for their quality or chosen methodology, as per scoping review methodology.
In accordance to step 5 and to answer the research questions, the included 64 publications were thematically categorized into five approaches according to the main contents of the studies. This categorization also assisted in bringing clarity and organization to the study.

\section{Approaches to HP in nursing homes utilized in the literature}

In the literature, Creating Ecological and Comprehensive Settings, Improving Quality of Life for Nursing Home Residents, Offering Person-Centered Care, Offering Relationship-Centered Care, and Activities Focusing on Workplace Health Promotion, were identified as relevant approaches to fostering HP for residents and staff in the NH setting. In Offering Person-Centered Care, we have made further sub-categories, in order to aid in the understanding of this many-sided approach (see Table 2 for their brief description).

Some conceptual overlap is present among the approaches, as HP is multifaceted and does intersect with many other concepts and practices in health care. However, each article was categorized according to its main focus (see Table 3).

In the Creating Ecological and Comprehensive Settings approach, four articles offered various perspectives as to how this approach could be integrated into NHs, and why it is especially suited for this setting $(5 ; 7 ; 15 ; 16)$. In the Improving Quality of Life for Nursing Home Residents approach, eight articles explored how this approach could be applied to NHs, as follows: via exploring the subjective perspectives of residents $(3 ; 17 ; 18)$, through theories $(9 ; 19 ; 20)$ and models $(21 ; 22)$, and through integration of aspects of residents' spirituality (23). 
Table 2. Approaches and sub-categories applying health promotion in nursing homes

\begin{tabular}{ll}
\hline Approach & Description (relevant to the nursing home setting) \\
\hline Creating Ecological & The Ecological Approach links the health of individuals to where they live and to the health of the ecosystem. It emphasizes \\
and Comprehensive & $\begin{array}{l}\text { that individuals cannot be viewed in isolation from their larger social and environmental units, and in order to have a holistic } \\
\text { understanding of health and disease, the systems and settings that people are situated within, must be incorporated. } \\
\text { A Comprehensive Settings Approach denotes that: the HP needs of multiple target groups are focused upon, health } \\
\text { is understood as being multi-dimensional, and multiple strategies are utilized (5). The Ecological Approach views the } \\
\text { Determinants of Health as being mainly social or environmental in nature and that individuals often do not have direct } \\
\text { control over them (7). A settings approach focuses on the entire system or organization when introducing changes which } \\
\text { will promote health for those influenced by it (15). The usual settings for HP consist of, for example, hospital, schools, and } \\
\text { workplaces. NHs have not been typically viewed of as being a setting for HP. }\end{array}$ \\
\hline
\end{tabular}

Improving Quality of Life for Nursing Home Residents

Offering PersonCentered Care

- Culture Change Movement (CCM)
In order to promote the health and well-being of $\mathrm{NH}$ residents, it is also essential to examine what good QoL is for them. The concept of QoL has been applied to NHs; however, debate remains as to what QoL in a NH entails. Despite a lack of conceptual clarity, it is important to recognize that what is considered routine for people living at home (autonomy, dignity, food enjoyment, comfort and safety) becomes essential in a NH environment (18).

One aspect of Offering Person-Centered Care is that care-staff are responsive to the needs of the NH residents, instead of focusing on fixed time schedules and task-oriented institutional norms (25). The residents are central in the care, and their needs and personal biographies are a top priority. Importantly, care-staff must also experience caring relationships with their management and leaders to provide Person-Centered Care with the residents.

A movement which aims to translate Person-Centered Care into NH practice, is a group of models and programs termed the CCM. The CCM is a collection of systematic changes to a NH organizational culture, and includes the following guidelines: (1) care and NH activities are guided by the NH resident; (2) environments are home-like rather than institutional-like; (3) close relationships are formed amongst NH residents, family members, personnel and the surrounding community; (4) work is organized in a way that promotes and assists staff in responding to NH residents' needs and wishes as a team; (5) management supports joint and decentralized decision-making, (6) continuous quality improvement occurs via systematic processes that are measurement-based and broad $(25 ; 48)$.

In order to bring clarity to the CCM, the various models within the CCM will be defined in the following sub-categories:

The Eden Alternative: This model was developed in 1991 by Dr William Thomas, an American geriatrician. It fosters autonomy, independence, and choice for the NH residents along with a warm and caring environment which is similar to home, in which pets, gardens, and possibilities for $\mathrm{NH}$ residents to build ongoing relationships with children and the community are present $(50 ; 51)$. It aims to alleviate feelings of boredom, loneliness and helplessness. 10 principles intended to empower and enable the older persons in having meaningful lives are central to this model.

The Green House Model: This model differs from the Eden Alternative, in that in addition to major changes in the philosophy of care and the organization of the staff, it also entails a radical conversion of the physical environment. It was designed to be a self-contained home for a small group of $\mathrm{NH}$ residents ( 7 to 10 persons) with private bathrooms, smart technology and Shahbazim (elder assistants). The surrounding community is also encouraged to engage with the NH residents (54). This model is a radical conversion of the physical environment, of the philosophy of care, and of the organization of the staff.

The Wellspring Model: This model is based upon an alliance of non-profit, independent NH, which started in eastern Wisconsin, USA. The NHs in the alliance collaborated to share their resources and their expertise to create a better environment for their staff and NH residents (55). Advanced practice nurses translate research-based evidence to all involved staff to transform and improve their everyday clinical practice and the daily care of the NH residents. This model is focused around the following principles: collaboration and cooperation among facilities, empowerment of staff, decision making based on data, accountability between the $\mathrm{NH}$ in the alliance for improving $\mathrm{NH}$ residents outcomes, designation of the same staff to groups of $\mathrm{NH}$ residents (55)

The Holistic Approach to Transformational Change (HAtch Model): This model was developed by the Quality Partners of Rhode Island, USA, in 2006. It is a change model designed to be utilized by long term care facilities to assist in the transformation from an institutional culture (medical model) to a Person-Centered Care culture (49). It influences change at the individual, organizational, community and systems levels via the following six domains: workplace practice, care practice, environment, leadership, family and community, and regulatory/government. It aims to improve the quality of care and life satisfaction for $\mathrm{NH}$ residents, their families and staff, and to increase the workforce retention (49).

The Live Oak Regenerative Community: This model originated in 1977. Its philosophy focuses on regenerating a culture in which elders evolve and transform not to mitigate problems, but as a healthy context to aging. A central and vital activity that occurs every morning is the Live Oak community meeting in the $\mathrm{NH}(56)$.

The Pioneer Network: This network is a non-profit center, based in Rochester, NY, USA, which was formed for all stakeholders in the field of aging who provide home or community for the older persons. The purpose is to offer assistance and knowledge dissemination to those who seek to transform their organization to one of a CCM model, and to support public policy changes and research.

Offering Relationship- Offering Relationship-Centered Care is quite similar to Offering Person-Centered Care; however, the emphasis lies in the Centered Care interaction among people, and that the relationship is the basis for any therapeutic encounter. According to Nolan et al., a sense of satisfaction and of positive outcomes is important for both patients and practitioners (57). It was emphasized that relationships exist between patients, their families, staff from all disciplines as well as the wider community.

Activities Focusing on Workplace Health Promotion
Along with providing nurturing relationships and supportive environments for NH residents, a healthy workplace for the staff in $\mathrm{NH}$ is also of the upmost of importance. The health of the workers, which is greatly influenced by the workplace environment, has a major influence upon the well-being of NH residents. This important correlation between a healthy workplace and $\mathrm{NH}$ residents cannot be underestimated (64). 


\section{Research and Best Practice}

Offering Person-Centered Care is a further approach facilitating moving away from a medical model towards promoting the health and well-being of $\mathrm{NH}$ residents and staff (24). Many publications were present for this approach, and they were focused on the following topics: its core concepts $(25 ; 26)$, promotion of a supportive environment (27-30), leadership and nursing competencies (31), the participation and empowerment of staff (32) and residents (33;34), evaluation (35-40), as well as design of spaces (41). The Culture Change Movement (CCM) (35;42-49), was organized as a sub-category of the Offering of Person-Centered Care (see Table 2). It was operationalized through specific models and programs such as the Eden Alternative (50;51), the Green House Model (52-54), the Well Spring Model (55), the HAtch Model (49), the Live Oak Regenerative Community (56), and the Pioneer Network (49).
Offering Relationship-Centered Care Approach has been considered as an alternative to the Person-Centered Care Approach, and this perspective was discussed in three publications (57-59). In 15 publications, activities focusing on Workplace Health Promotion in NHs were focused on through: leadership and management (6o-62), empowerment strategies (63-65), quality improvement processes (66-69), examination of workplace stressors (70), and HP programs for staff (71-74).

\section{Extent of health promotion systematically ap- plied in nursing homes}

In the previous section, the research question of how HP has been applied in the NH setting in the literature was examined through categorization of the included publications into five main approaches. In this section, the research question of the extent to which HP has systematically been applied in the $\mathrm{NH}$ setting, will be explored (see Figure 3).

Table 3. Approach and main focus of the included publications

\begin{tabular}{lllll}
\hline Approach & Year & Author(s) & Country & Title \\
\hline Creating & 2014 & Krajic, & Austria & Health-promoting \\
$\begin{array}{l}\text { Ecological and } \\
\text { Comprehensive }\end{array}$ & & et al. & & $\begin{array}{l}\text { residential aged care: a } \\
\text { pilot project in Austria }\end{array}$ \\
Settings & & &
\end{tabular}

\section{Main focus}

Conducted a two- year pilot project in Austria: NHs were viewed as a comprehensive Health Promotion (HP) setting. It combined an organizational development focus with a controlled study on resident mobility enhancement. It demonstrated that this HP approach could be well implemented at the political, organizational, scientific and financial levels, and HP was viewed by the $\mathrm{NHs}$ as being beneficial to their organizational development (5).

\begin{tabular}{|c|c|c|c|c|c|}
\hline $\begin{array}{l}\text { Creating } \\
\text { Ecological and } \\
\text { Comprehensive } \\
\text { Settings }\end{array}$ & 2012 & $\begin{array}{l}\text { Harris \& } \\
\text { Grootjans }\end{array}$ & Australia & $\begin{array}{l}\text { The application of } \\
\text { ecological thinking to } \\
\text { better understand the } \\
\text { needs of communities }\end{array}$ & $\begin{array}{l}\text { Developed an ecological framework designed for use by NH staff } \\
\text { to improve the well-being of NH residents. It focused upon the } \\
\text { domains of the physical environment, the social environment, } \\
\text { governance and active living (7). }\end{array}$ \\
\hline
\end{tabular}

\begin{tabular}{|c|c|c|c|c|}
\hline & & & & of older people. \\
\hline $\begin{array}{l}\text { Creating } \\
\text { Ecological and } \\
\text { Comprehensive } \\
\text { Settings }\end{array}$ & 2008 & $\begin{array}{l}\text { Harris, } \\
\text { et al. }\end{array}$ & Australia & $\begin{array}{l}\text { Ecological Aging: The } \\
\text { Settings Approach in } \\
\text { Aged Living and Care } \\
\text { Accommodation }\end{array}$ \\
\hline
\end{tabular}

Introduced the Ecological Approach to $\mathrm{NHs}$ by paralleling $\mathrm{NHs}$ to Health Promoting Schools (15). Argued that applying an ecological perspective to NHs supports $\mathrm{NHs}$ in improving the well-being for the residents and that $\mathrm{NH}$ residents should not be isolated from society, as is common practice (15).

\begin{tabular}{|c|c|c|c|c|}
\hline $\begin{array}{l}\text { Creating } \\
\text { Ecological and } \\
\text { Comprehensive } \\
\text { Settings }\end{array}$ & 2012 & $\begin{array}{l}\text { Wahl, } \\
\text { et al. }\end{array}$ & $\begin{array}{l}\text { Germany \& } \\
\text { Sweden }\end{array}$ & $\begin{array}{l}\text { Aging Well and the } \\
\text { Environment: Toward } \\
\text { an Integrative Model } \\
\text { and Research Agenda } \\
\text { for the Future }\end{array}$ \\
\hline
\end{tabular}

Explained the interchange between the person and the environment and its effect on aging well. Core processes in aging well are belonging (a sense of a positive connection with others and the environment) and agency (being a change agent in one's own life via intentional or proactive behavior). In the case of major age-related functional impairment belonging increases in importance, whereas agency becomes less important (16).

\begin{tabular}{|c|c|c|c|c|}
\hline $\begin{array}{l}\text { Improving } \\
\text { Quality of Life } \\
\text { for Nursing }\end{array}$ & 2012 & $\begin{array}{l}\text { Brownie \& } \\
\text { Horstmanshof }\end{array}$ & Australia & $\begin{array}{l}\text { Creating the conditions } \\
\text { for self-fulfilment for } \\
\text { aged care residents }\end{array}$ \\
\hline
\end{tabular}
$\mathrm{NHs}$ can constrain and limit residents' entitlements to human rights such as independence, participation, care, self-fulfilment, and dignity, thereby negatively affecting their QoL. To prevent this from occurring, NHs need to ensure that attention is given to the following characteristics of a good life, which were identified by residents: personal identity and self-esteem, meaningful relationships, personal control and autonomy, home and personal surroundings, meaningful daily and community life, and personalized support and care (3).

\begin{tabular}{|c|c|c|c|c|c|}
\hline $\begin{array}{l}\text { Improving } \\
\text { Quality of Life } \\
\text { for Nursing } \\
\text { Home Residents }\end{array}$ & 2013 & $\begin{array}{l}\text { Van Malderen, } \\
\text { et al. }\end{array}$ & Belgium & $\begin{array}{l}\text { The Active Ageing } \\
\text { Concept translated to } \\
\text { the residential long- } \\
\text { term care }\end{array}$ & $\begin{array}{l}\text { It was proposed that meaningful leisure and participation be } \\
\text { added to the active aging determinants, in order to make them } \\
\text { applicable to improving the QoL for NH residents (9). }\end{array}$ \\
\hline
\end{tabular}


Table 3. Continued

\begin{tabular}{lllll}
\hline Approach & Year & Author(s) & Country & Title \\
\hline $\begin{array}{l}\text { Improving } \\
\begin{array}{l}\text { Quality of Life } \\
\text { for Nursing } \\
\text { Home Residents }\end{array}\end{array}$ & 2012 & $\begin{array}{l}\text { Bradshaw, } \\
\text { et al. }\end{array}$ & UK & $\begin{array}{l}\text { Living well in care } \\
\text { homes: a systematic } \\
\text { review of qualitative } \\
\text { studies }\end{array}$ \\
\hline $\begin{array}{l}\text { Improving } \\
\begin{array}{l}\text { Quality of Life } \\
\text { for Nursing } \\
\text { Home Residents }\end{array}\end{array}$ & 2003 & Kane, & USA & $\begin{array}{l}\text { Quality of Life } \\
\text { et al. }\end{array}$ \\
\end{tabular}

\section{Main focus}

Attaining NH residents' perspectives is also essential when striving for good QoL among NH residents. They expressed concerns regarding a lack of autonomy and problems in forming relationships and identified the following four key themes that affect good QoL: acceptance and adaptation, connectedness with others, a homelike environment, and caring practices (17).

To provide NHs with a tool for measuring residents' perceptions of QoL, and thereby enable them to take measures to improve the residents' QoL, Kane et al (2003), developed a scale based upon what constitutes QOL from NH residents' subjective perspectives: comfort, security, meaningful activity, relationships, functional competence, enjoyment, privacy, dignity, autonomy, and spiritual well-being (18).

\begin{tabular}{|c|c|c|c|c|}
\hline $\begin{array}{l}\text { Improving } \\
\text { Quality of Life } \\
\text { for Nursing } \\
\text { Home Residents }\end{array}$ & 2004 & Gerritsen, et al. & Netherlands & $\begin{array}{l}\text { Finding a useful } \\
\text { conceptual basis for } \\
\text { enhancing the quality } \\
\text { of life of nursing home } \\
\text { residents }\end{array}$ \\
\hline $\begin{array}{l}\text { Improving } \\
\text { Quality of Life } \\
\text { for Nursing } \\
\text { Home Residents }\end{array}$ & 2013 & $\begin{array}{l}\text { Van Malderen, } \\
\text { et al. }\end{array}$ & Belgium & $\begin{array}{l}\text { Interventions to enhan- } \\
\text { ce the Quality of Life of } \\
\text { older people in residen- } \\
\text { tial long-term care: A } \\
\text { systematic review }\end{array}$ \\
\hline $\begin{array}{l}\text { Improving } \\
\text { Quality of Life } \\
\text { for Nursing } \\
\text { Home Residents }\end{array}$ & 2012 & $\begin{array}{l}\text { Zubritsky, } \\
\text { et al. }\end{array}$ & USA & $\begin{array}{l}\text { Health-related Quality } \\
\text { of Life: Expanding a } \\
\text { Conceptual Framework } \\
\text { to Include Older Adults } \\
\text { Who Receive Long-term } \\
\text { Services and Supports }\end{array}$ \\
\hline $\begin{array}{l}\text { Improving } \\
\text { Quality of Life } \\
\text { for Nursing } \\
\text { Home Residents }\end{array}$ & 2018 & $\begin{array}{l}\text { Rinnan, } \\
\text { et al. }\end{array}$ & Norway & $\begin{array}{l}\text { Joy of life in nursing } \\
\text { homes: A qualitative } \\
\text { study of what } \\
\text { constitutes the essence } \\
\text { of Joy of life in elderly } \\
\text { individuals living in } \\
\text { Norwegian nursing } \\
\text { homes }\end{array}$ \\
\hline
\end{tabular}

It is suggested that the most suitable QoL framework to provide a basis for guideline development for improving QOL among $\mathrm{NH}$ residents, is the Theory of Social Production Functions. A key factor of good QoL of $\mathrm{NH}$ residents is the fit between the residents, and the structure and process of the care provided (19).

In the articles of this systematic review, the Interventions focusing on improving the QoL for $\mathrm{NH}$ residents in accordance to these adapted nine active aging determinants either did not exist, or were only targeted to either the physical activity or the psychological factors of $\mathrm{NH}$ residents (20).

The Wilson and Cleary health related QoL model was expanded upon, so that it was applicable to NHs. This was done through the addition of cognitive ability and behavioral status of the resident, as well as the environmental characteristics of the $\mathrm{NH}$ organization (21).

Various districts in Norway are utilizing a certification program, the 'Joy of Life Nursing Home', which is based upon a HP perspective (with salutogenesis functioning as the main conceptual 'umbrella'). Through health promotion, preventive and social activities across generations, $\mathrm{NH}$ care under this program, aims to promote respect, wellbeing, health and cultural involvement with their residents (to promote well-being \& flourishing). This study conducted individual qualitative research interviews with 29 residents, to explore the phenomena 'Joy of Life'. The results revealed that positive relations, a sense of belonging, sources of meaning, moments of feeling well, and acceptance, constituted the essence of this program (22).

\begin{tabular}{|c|c|c|c|c|}
\hline $\begin{array}{l}\text { Improving } \\
\text { Quality of Life } \\
\text { for Nursing } \\
\text { Home Resident }\end{array}$ & 2016 & $\begin{array}{l}\text { Haugan, } \\
\text { et al. }\end{array}$ & Norway & $\begin{array}{l}\text { Intrapersonal self- } \\
\text { transcendence, meaning- } \\
\text { in-life and nurse-patient } \\
\text { interaction: powerful }\end{array}$ \\
\hline
\end{tabular}

Reported that certain aspects of spirituality, especially self-transcendence and meaning, along with nurse-patient interaction, were of key importance in enhancing NH residents' QoL (23). interaction: powerful assets for quality of life in cognitively intact nursinghome patients

\begin{tabular}{|c|c|c|c|c|}
\hline $\begin{array}{l}\text { Offering Per- } \\
\text { son-Centered } \\
\text { Care }\end{array}$ & 2019 & $\begin{array}{l}\text { Vassbo, } \\
\text { et al. }\end{array}$ & Norway & $\begin{array}{l}\text { The meaning of working } \\
\text { in a person-centred } \\
\text { way in nursing homes: } \\
\text { a phenomenological- } \\
\text { hermeneutical study }\end{array}$ \\
\hline
\end{tabular}

\begin{tabular}{|c|c|c|c|c|c|}
\hline $\begin{array}{l}\text { Offering Per- } \\
\text { son-Centered } \\
\text { Care }\end{array}$ & 2012 & $\begin{array}{l}\text { McCormack, } \\
\text { et al. }\end{array}$ & Various & $\begin{array}{l}\text { Appreciating the } \\
\text { 'person' in long-term } \\
\text { care }\end{array}$ & $\begin{array}{l}\text { It is especially important that the registered nurse ensures that } \\
\text { the essence of Person-Centered Care is practiced, especially } \\
\text { through the formation of meaningful relationships with the } \\
\text { residents, families, and work colleagues (25). }\end{array}$ \\
\hline $\begin{array}{l}\text { Offering Per- } \\
\text { son-Centered } \\
\text { Care }\end{array}$ & 2004 & McCormack & UK & $\begin{array}{l}\text { Person-centredness in } \\
\text { gerontological nursing: } \\
\text { an overview of the } \\
\text { literature }\end{array}$ & $\begin{array}{l}\text { The following four core concepts underpin Person-Centered Care } \\
\text { in NHs: 1) people exist in relationships with others; } 2 \text { ) people } \\
\text { are social beings; } 3 \text { ) people express their personality through } \\
\text { their own context; 4) how people are recognized, respected and } \\
\text { trusted, affects their sense of self (26). }\end{array}$ \\
\hline
\end{tabular}


Table 3. Continued

\begin{tabular}{|c|c|c|c|c|c|}
\hline Approach & Year & Author(s) & Country & Title & Main focus \\
\hline $\begin{array}{l}\text { Offering Per- } \\
\text { son-Centered } \\
\text { Care }\end{array}$ & 2010 & $\begin{array}{l}\text { McCormack, } \\
\text { et al. }\end{array}$ & $\begin{array}{l}\text { Ireland \& } \\
\text { Australia }\end{array}$ & $\begin{array}{l}\text { Developing person- } \\
\text { centred practice: nursing } \\
\text { outcomes arising from } \\
\text { changes to the care envi- } \\
\text { ronment in residential } \\
\text { settings for older people }\end{array}$ & $\begin{array}{l}\text { In order for Person-Centered Care practice to be possible, } \\
\text { a supportive care environment was necessary, including } \\
\text { effective teamwork, workload and time management, and staff } \\
\text { relationships (27). }\end{array}$ \\
\hline $\begin{array}{l}\text { Offering Per- } \\
\text { son-Centered } \\
\text { Care }\end{array}$ & 2019 & $\begin{array}{l}\text { Boscart, } \\
\text { et al. }\end{array}$ & Canada & $\begin{array}{l}\text { Neighbourhood } \\
\text { Team Development } \\
\text { to promote resident } \\
\text { centred approaches } \\
\text { in nursing homes: a } \\
\text { protocol for a multi } \\
\text { component intervention }\end{array}$ & $\begin{array}{l}\text { A protocol is described, which is used to implement and evaluate } \\
\text { 'Neighbourhood Team Development' (with } 32 \text { residents), which } \\
\text { consists of three components: " } 1 \text {. Modifying the physical NH } \\
\text { environment, } 2 \text {. Reorganizing the organization and delivery of } \\
\text { care and services, and 3. Aligning team members to collaborate } \\
\text { in providing resident-centred care. In addition, NTD intentionally } \\
\text { includes strategies to address traditional organizational design } \\
\text { and skills misalignment" (pg.2) (28). }\end{array}$ \\
\hline $\begin{array}{l}\text { Offering Per- } \\
\text { son-Centered } \\
\text { Care }\end{array}$ & 2014 & $\begin{array}{l}\text { Sjögren, } \\
\text { et al. }\end{array}$ & Sweden & $\begin{array}{l}\text { To what extent is the } \\
\text { work environment of } \\
\text { staff related to person } \\
\text { centred care? A cross } \\
\text { sectional study of } \\
\text { residential aged care }\end{array}$ & $\begin{array}{l}\text { Revealed that higher levels of Person-Centered Care were } \\
\text { correlated with increased perceived levels of satisfaction with } \\
\text { their workplace and the care provided, decreased levels of stress } \\
\text { of conscience and job strain, and a supportive psychosocial } \\
\text { climate (29). }\end{array}$ \\
\hline $\begin{array}{l}\text { Offering Per- } \\
\text { son-Centered } \\
\text { Care }\end{array}$ & 2012 & $\begin{array}{l}\text { Siegel, } \\
\text { et al. }\end{array}$ & $\begin{array}{l}\text { USA \& } \\
\text { Canada }\end{array}$ & $\begin{array}{l}\text { Supporting and promo- } \\
\text { ting personhood in } \\
\text { long term care settings: } \\
\text { contextual factors }\end{array}$ & $\begin{array}{l}\text { The sociocultural, public policy, financing, regulatory, } \\
\text { professional, and organizational contexts in which registered } \\
\text { nurses are confronted with also have a major influence in their } \\
\text { capacity to deliver Person-Centered Care (30). }\end{array}$ \\
\hline $\begin{array}{l}\text { Offering Per- } \\
\text { son-Centered } \\
\text { Care }\end{array}$ & 2012 & $\begin{array}{l}\text { Mueller, } \\
\text { et al. }\end{array}$ & USA & $\begin{array}{l}\text { Nurse Competencies for } \\
\text { Person-Directed Care in } \\
\text { Nursing Homes }\end{array}$ & $\begin{array}{l}\text { To facilitate Person-Centered Care delivery in NHs, strong } \\
\text { leadership in both management and among registered nurses is } \\
\text { vital, and compentencies were recommended: } 1 \text { ) modelling the } \\
\text { Person-Centered Care Approach; } 2 \text { ) focusing on effective, shared } \\
\text { team work with care staff, residents and their families; and 3) } \\
\text { promoting a home-like environment and a positive workplace (31). }\end{array}$ \\
\hline $\begin{array}{l}\text { Offering Per- } \\
\text { son-Centered } \\
\text { Care }\end{array}$ & 2012 & $\begin{array}{l}\text { Coleman \& } \\
\text { Medvene }\end{array}$ & USA & $\begin{array}{l}\text { A Person-Centered } \\
\text { Care Intervention for } \\
\text { Geriatric Certified } \\
\text { Nursing Assistants }\end{array}$ & $\begin{array}{l}\text { Aimed to increase the participation and engagement of staff. } \\
\text { They targeted their action on videotaping caregiving interactions } \\
\text { between NH residents and Care Aides, to assist staff in acquiring } \\
\text { the skills necessary to promote Person-Centered Care (32). }\end{array}$ \\
\hline $\begin{array}{l}\text { Offering Per- } \\
\text { son-Centered } \\
\text { Care }\end{array}$ & 2011 & $\begin{array}{l}\text { Shura, } \\
\text { et al. }\end{array}$ & USA & $\begin{array}{l}\text { Culture Change in Long- } \\
\text { term Care: Paricipatory } \\
\text { Action Research and the } \\
\text { Role of the Resident }\end{array}$ & $\begin{array}{l}\text { Participatory Action Research with } \mathrm{NH} \text { residents was proposed } \\
\text { because it promotes meaningful social engagement and tackles } \\
\text { the ageist modes of relationships with residents (33). }\end{array}$ \\
\hline $\begin{array}{l}\text { Offering Per- } \\
\text { son-Centered } \\
\text { Care }\end{array}$ & 2011 & $\begin{array}{l}\text { Perry, } \\
\text { et al. }\end{array}$ & Australia & $\begin{array}{l}\text { Examination of the utili- } \\
\text { ty of the Promoting Ac- } \\
\text { tion on Research Imple- } \\
\text { mentation in Health Ser- } \\
\text { vices framework for im- } \\
\text { plementation of eviden- } \\
\text { ce based practice in resi- } \\
\text { dential aged care settings }\end{array}$ & $\begin{array}{l}\text { Promoting Action on Research Implementation in Health Services } \\
\text { Framework was recommended to improve knowledge translation } \\
\text { and practice change in } \mathrm{NHs}(34) \text {. }\end{array}$ \\
\hline $\begin{array}{l}\text { Offering Per- } \\
\text { son-Centered } \\
\text { Care }\end{array}$ & 2013 & $\begin{array}{l}\text { Brownie \& } \\
\text { Nancarrow }\end{array}$ & Australia & $\begin{array}{l}\text { Effects of person- } \\
\text { centered care on } \\
\text { residents and staff in } \\
\text { aged-care facilities: a } \\
\text { systematic review }\end{array}$ & $\begin{array}{l}\text { Person-Centered Care interventions are multifactorial and include } \\
\text { elements such as changes to the physical and social environment, } \\
\text { to the philosophy of care, to leadership and management, and } \\
\text { to the empowerment of staff. Hence, evaluation is complex, and } \\
\text { further research was called for to evaluate these elements either } \\
\text { singly or in combination (35). }\end{array}$ \\
\hline $\begin{array}{l}\text { Offering Per- } \\
\text { son-Centered } \\
\text { Care }\end{array}$ & 2019 & $\begin{array}{l}\text { Cornelison, } \\
\text { Hermer, Syme } \\
\text { \& Doll }\end{array}$ & USA & $\begin{array}{l}\text { Initiating Aha moments } \\
\text { when implementing } \\
\text { person-centered care } \\
\text { in nursing homes: a } \\
\text { multi-arm, pre-post } \\
\text { intervention }\end{array}$ & $\begin{array}{l}\text { A multi-arm, pre/post intervention study was conducted to } \\
\text { examine how nursing homes perceive their adoption of PCC } \\
\text { practices across seven domains and how these perceptions } \\
\text { change in response to an educational intervention embedded in } \\
\text { a statewide program (36). }\end{array}$ \\
\hline
\end{tabular}


Table 3. Continued

\begin{tabular}{|c|c|c|c|c|}
\hline Approach & Year & Author(s) & Country & Title \\
\hline $\begin{array}{l}\text { Offering Per- } \\
\text { son-Centered } \\
\text { Care }\end{array}$ & 2020 & $\begin{array}{l}\text { Lima, Schwartz, } \\
\text { Clark \& Miller }\end{array}$ & USA & $\begin{array}{l}\text { The Changing Adoption } \\
\text { of Culture Change } \\
\text { Practices in U.S. Nursing } \\
\text { Homes }\end{array}$ \\
\hline
\end{tabular}

\section{Main focus}

The first national US study (with 1,584 US NHs) assessing NH Culture Change adoption. NHs were surveyed in 2009/2010 and 2016/2017.

Physical environment, staff empowerment, and resident-centered care domain scores were calculated at both time points. Multivariate logistic regression models examined factors associated with domain score increases. A lot of NHs increased their CC practices; however, many did not. The factors surrounding staff empowerment and improvements in regard to resident-centered care are not clear (37).

\begin{tabular}{llll}
\hline $\begin{array}{l}\text { Offering Per- } \\
\text { son-Centered }\end{array}$ & 2016 & $\begin{array}{l}\text { Edvardsson, } \\
\text { et al. }\end{array}$ & $\begin{array}{l}\text { Sweden, } \\
\text { Australia \& } \\
\text { Care }\end{array}$ \\
& & $\begin{array}{l}\text { Norway } \\
\end{array}$
\end{tabular}

The Umea ageing and Other research currently underway is expected to provide son-Centered et al. Australia \& health research properson-centred care and health-promoting living conditions for an ageing population

\begin{tabular}{|c|c|c|c|c|}
\hline $\begin{array}{l}\text { Offering Per- } \\
\text { son-Centered } \\
\text { Care }\end{array}$ & 2008 & $\begin{array}{l}\text { White, } \\
\text { Newton-Curtis } \\
\text { \& Lyons }\end{array}$ & USA & $\begin{array}{l}\text { Development and Initial } \\
\text { Testing of a Measure of } \\
\text { Person-Directed Care }\end{array}$ \\
\hline
\end{tabular}
the outcomes, structure and content of both healthpromoting living conditions in NHs and of Person-Centered Care for older persons and older persons with dementia who either live at home, in sheltered housing or in $\mathrm{NHs}$ (38).

The initial assessment and testing of a tool, which was focused on the constructs of autonomy, personhood, knowing the person, comfort, supportive relationships, working with residents, the residents' personal environment, and the structure of management, was expected to be useful in evaluating the effectiveness in meeting the per- son-directed care goals, but further testing was recommended (39).

\begin{tabular}{|c|c|c|c|c|c|}
\hline $\begin{array}{l}\text { Offering Per- } \\
\text { son-Centered } \\
\text { Care }\end{array}$ & 2010 & $\begin{array}{l}\text { Edvardsson \& } \\
\text { Innes }\end{array}$ & $\begin{array}{l}\text { Sweden, } \\
\text { Australia } \\
\text { \& UK }\end{array}$ & $\begin{array}{l}\text { Measuring Person- } \\
\text { centered Care: A Criti- } \\
\text { cal Comparative Review } \\
\text { of Published Tools }\end{array}$ & $\begin{array}{l}\text { More research was also advised in the evaluation of existing tools } \\
\text { which aim to measure Person-Centered Care in NHs, including NH } \\
\text { residents with dementia (40). }\end{array}$ \\
\hline $\begin{array}{l}\text { Offering Per- } \\
\text { son-Centered } \\
\text { Care }\end{array}$ & 2011 & $\begin{array}{l}\text { Pomeroy, } \\
\text { et al. }\end{array}$ & $\begin{array}{l}\text { USA \& } \\
\text { Thailand }\end{array}$ & $\begin{array}{l}\text { Person - Environment Fit } \\
\text { and Functioning Among } \\
\text { Older Adults in a Long- } \\
\text { Term Care Setting }\end{array}$ & $\begin{array}{l}\text { When designing critical spaces within a Person-Centered Care } \\
\text { Approach, particular attention should be given to maximizing the } \\
\text { function and the physical activity of the NH residents (41). }\end{array}$ \\
\hline $\begin{array}{l}\text { Offering Per- } \\
\text { son-Centered } \\
\text { Care: } \mathrm{CCM}\end{array}$ & 2013 & $\begin{array}{l}\text { Hartmann, } \\
\text { et al. }\end{array}$ & USA & $\begin{array}{l}\text { A conceptual model } \\
\text { for culture change } \\
\text { evaluation in nursing } \\
\text { homes }\end{array}$ & $\begin{array}{l}\text { Development of a conceptual model, "Nursing Home Integrated } \\
\text { Model for Producing and Assessing Cultural Transformation (Nursing } \\
\text { Home IMPACT)": it is based upon the categories of environment of } \\
\text { care, care practices, workplace practices and meta constructs. It also } \\
\text { focuses on looking at progress from multiple perspectives, such as } \\
\text { staff, residents', residents' families, and management (43). }\end{array}$ \\
\hline $\begin{array}{l}\text { Offering Per- } \\
\text { son-Centered } \\
\text { Care: CCM }\end{array}$ & 2009 & $\begin{array}{l}\text { White-Chu, } \\
\text { et al. }\end{array}$ & USA & $\begin{array}{l}\text { Beyond the Medical } \\
\text { Model: The Culture } \\
\text { Change Revolution in } \\
\text { Long-Term Care }\end{array}$ & $\begin{array}{l}\text { Expert discussion article: The involvement of physicians is } \\
\text { strongly called for in order to advance the Culture Change } \\
\text { Movement, and also because it would promote physicians' } \\
\text { image of being advocates for improving the QoL and for patient- } \\
\text { centered care among NH residents (44). }\end{array}$ \\
\hline $\begin{array}{l}\text { Offering Per- } \\
\text { son-Centered } \\
\text { Care: CCM }\end{array}$ & 2008 & $\begin{array}{l}\text { Rahman \& } \\
\text { Schnelle }\end{array}$ & USA & $\begin{array}{l}\text { The Nursing Home } \\
\text { Culture-Change Move- } \\
\text { ment: Recent Past, } \\
\text { Present, and Future } \\
\text { Directions for Research }\end{array}$ & $\begin{array}{l}\text { Retrospective critique of research base underlying the nursing } \\
\text { home culture change movement: the evidence base of the } \\
\text { Culture Change Movement is underdeveloped ( } 45) \text {. }\end{array}$ \\
\hline $\begin{array}{l}\text { Offering Per- } \\
\text { son-Centered } \\
\text { Care: } \mathrm{CCM}\end{array}$ & 2011 & $\begin{array}{l}\text { Hill, } \\
\text { et al. }\end{array}$ & USA & $\begin{array}{l}\text { Culture Change Models } \\
\text { and Resident Health } \\
\text { Outcomes in Long-Term } \\
\text { Care }\end{array}$ & $\begin{array}{l}\text { The evidence base of the Culture Change Movement is } \\
\text { underdeveloped (46). }\end{array}$ \\
\hline
\end{tabular}


Table 3. Continued

\begin{tabular}{|c|c|c|c|c|c|}
\hline Approach & Year & Author(s) & Country & Title & Main focus \\
\hline $\begin{array}{l}\text { Offering Per- } \\
\text { son-Centered } \\
\text { Care: } \mathrm{CCM}\end{array}$ & 2010 & Koren & USA & $\begin{array}{l}\text { Person-Centered Care } \\
\text { for Nursing Home } \\
\text { Residents: The Culture- } \\
\text { Change Movement }\end{array}$ & $\begin{array}{l}\text { Many aspects of the } \mathrm{NH} \text { industry impede culture change in } \mathrm{NH} \\
\text { due to its regulations, workforce and reimbursement policies, } \\
\text { further reinforcing the medical model }(48) \text {. }\end{array}$ \\
\hline $\begin{array}{l}\text { Offering Per- } \\
\text { son-Centered } \\
\text { Care: CCM }\end{array}$ & 2011 & Jones & USA & $\begin{array}{l}\text { Person-Centered Care: } \\
\text { The Heart of Culture } \\
\text { Change }\end{array}$ & $\begin{array}{l}\text { Educational article for nurses: describes Person-Centered Care } \\
\text { and the Culture Change Movement (49). }\end{array}$ \\
\hline $\begin{array}{l}\text { Offering Per- } \\
\text { son-Centered } \\
\text { Care: CCM - } \\
\text { The Eden } \\
\text { Alternative }\end{array}$ & 2010 & $\begin{array}{l}\text { Petersen \& } \\
\text { Warbuton }\end{array}$ & Australia & $\begin{array}{l}\text { The Eden Model: } \\
\text { Innovation in Australian } \\
\text { aged care? }\end{array}$ & $\begin{array}{l}\text { The Eden Alternative program was implemented in one small } \\
\text { integrated health service area in rural Australia and it was found } \\
\text { that this model may not be as transformative as it is marketed } \\
\text { to be, because person-centred practice already existed there. } \\
\text { However, it was also concluded that rigourous academic research } \\
\text { was lacking (50). }\end{array}$ \\
\hline $\begin{array}{l}\text { Offering Per- } \\
\text { son-Centered } \\
\text { Care: CCM } \\
\text { - The Eden } \\
\text { Alternative } \\
\end{array}$ & 2003 & Monkhouse & Switzerland & $\begin{array}{l}\text { Beyond the Medical } \\
\text { Model - The Eden } \\
\text { Alternative in Practice: } \\
\text { A Swiss Experience }\end{array}$ & $\begin{array}{l}\text { In two NHs in Switzerland, this model was described as being } \\
\text { successfully implemented and that it assisted with alleviating } \\
\text { loneliness, helplessness and boredom among the NH residents } \\
\text { (51). }\end{array}$ \\
\hline $\begin{array}{l}\text { Offering Per- } \\
\text { son-Centered } \\
\text { Care: CCM - The } \\
\text { Greenhouse } \\
\text { Model }\end{array}$ & 2008 & $\begin{array}{l}\text { Ragsdale \& } \\
\text { McDoug-all }\end{array}$ & USA & $\begin{array}{l}\text { The changing face of } \\
\text { long-term care: looking } \\
\text { at the past decade }\end{array}$ & $\begin{array}{l}\text { The Greenhouse Model is thought to hold a lot of potential for } \\
\text { improving residents' QoL. More systematic investigations was } \\
\text { deemed necessary (52). }\end{array}$ \\
\hline $\begin{array}{l}\text { Offering Per- } \\
\text { son-Centered } \\
\text { Care: CMM - } \\
\text { The Greenhouse } \\
\text { Model }\end{array}$ & 2016 & $\begin{array}{l}\text { Zimmerman, } \\
\text { et al. }\end{array}$ & USA & $\begin{array}{l}\text { New Evidence on the } \\
\text { GreenHouse Model of } \\
\text { Nursing Home Care: } \\
\text { Synthesis of Findings } \\
\text { and Implications for } \\
\text { Policy, Practice, and } \\
\text { Research }\end{array}$ & $\begin{array}{l}\text { Between } 2011 \text { and 2014, an evaluation the largest and most } \\
\text { coordinated evaluation to date was conducted concerning the } \\
\text { outcomes and care processes in the Green House Model. The } \\
\text { main findings were that implementation of the model was } \\
\text { not consistent among NHs in regards to variation in practices } \\
\text { supporting resident choice and in clinical decision-making. } \\
\text { The model lowered hospital readmissions, it improved three } \\
\text { measures of poor quality (bedfast residents, catheterized } \\
\text { residents and pressure ulcers), along with a reduction in some } \\
\text { expenditures. Additionally, there was evidence pointing towards } \\
\text { a reduction in direct staff turnover (53). }\end{array}$ \\
\hline $\begin{array}{l}\text { Offering Per- } \\
\text { son-Centered } \\
\text { Care: CMM - } \\
\text { The Greenhouse } \\
\text { Model }\end{array}$ & 2006 & $\begin{array}{l}\text { Rabig, } \\
\text { et al. }\end{array}$ & USA & $\begin{array}{l}\text { Radical Redesign } \\
\text { of Nursing Homes: } \\
\text { Applying the Green } \\
\text { House Concept in } \\
\text { Tupelo, Mississippi }\end{array}$ & $\begin{array}{l}\text { The first implementation of this model was in Tupelo, Mississippi, } \\
\text { USA. It was believed that the outcomes were likely to be } \\
\text { favorable; however, there were concerns regarding the major } \\
\text { physical restructuring aspects (54). }\end{array}$ \\
\hline $\begin{array}{l}\text { Offering Per- } \\
\text { son-Centered } \\
\text { Care: CMM - } \\
\text { The Wellspring } \\
\text { Model }\end{array}$ & 2003 & $\begin{array}{l}\text { Kehoe \& Van } \\
\text { Heesch }\end{array}$ & USA & $\begin{array}{l}\text { Culture Change in } \\
\text { Long Term Care: The } \\
\text { Wellspring Model }\end{array}$ & $\begin{array}{l}\text { Implementation of the Wellspring Model among eleven NHs } \\
\text { in Wisconson, USA revealed that outcomes stemming from } \\
\text { an evaluation undertaken by the Institute for the Future of } \\
\text { Aging Services were positive. This model combined quality } \\
\text { improvement in clinical care with culture change in the } \\
\text { organization to improve quality in NHs (55). }\end{array}$ \\
\hline $\begin{array}{l}\text { Offering Per- } \\
\text { son-Centered } \\
\text { Care: CMM - } \\
\text { The HAtch } \\
\text { Model }\end{array}$ & 2011 & Jones & USA & $\begin{array}{l}\text { Person-Centered Care: } \\
\text { The Heart of Culture } \\
\text { Change }\end{array}$ & $\begin{array}{l}\text { Description of the HAtch Model: designed to facilitate the } \\
\text { delivery of different Culture Change models, in order for NHs } \\
\text { to make the transition to person-centered care practices. This } \\
\text { change model is deemed necessary to make a transformational } \\
\text { change in the way care is provided (49). }\end{array}$ \\
\hline $\begin{array}{l}\text { Offering Per- } \\
\text { son-Centered } \\
\text { Care: CCM - } \\
\text { The Live Oak } \\
\text { Regenerative } \\
\text { Community }\end{array}$ & 2003 & Barkan & USA & $\begin{array}{l}\text { The Live Oak } \\
\text { Regenerative } \\
\text { Community: } \\
\text { Championing a Culture } \\
\text { of Hope and Meaning }\end{array}$ & $\begin{array}{l}\text { Description of the Live Oak Regenerative Community Model: } \\
\text { centres around building a healthy culture for aging and intends } \\
\text { to create new roles for elders. These new roles are based around } \\
\text { the cultivation of a spiritual community, wherein the elders ( } \mathrm{NH} \\
\text { residents) are connected to one another and their surrounding } \\
\text { community and have a positive vision of what being an elder in } \\
\text { their culture means (56). }\end{array}$ \\
\hline $\begin{array}{l}\text { Offering Per- } \\
\text { son-Centered } \\
\text { Care: CCM - } \\
\text { The Pioneer } \\
\text { Network }\end{array}$ & 2011 & Jones & USA & $\begin{array}{l}\text { Person-Centered Care: } \\
\text { The Heart of Culture } \\
\text { Change }\end{array}$ & $\begin{array}{l}\text { Description of the Pioneer Network: functions as an advocacy } \\
\text { organization for the Culture Change Movement and aims to } \\
\text { disseminate knowledge to NHs who would like to transform their } \\
\text { organization to a model within the Culture Change Movement } \\
\text { (49). }\end{array}$ \\
\hline
\end{tabular}


Table 3. Continued

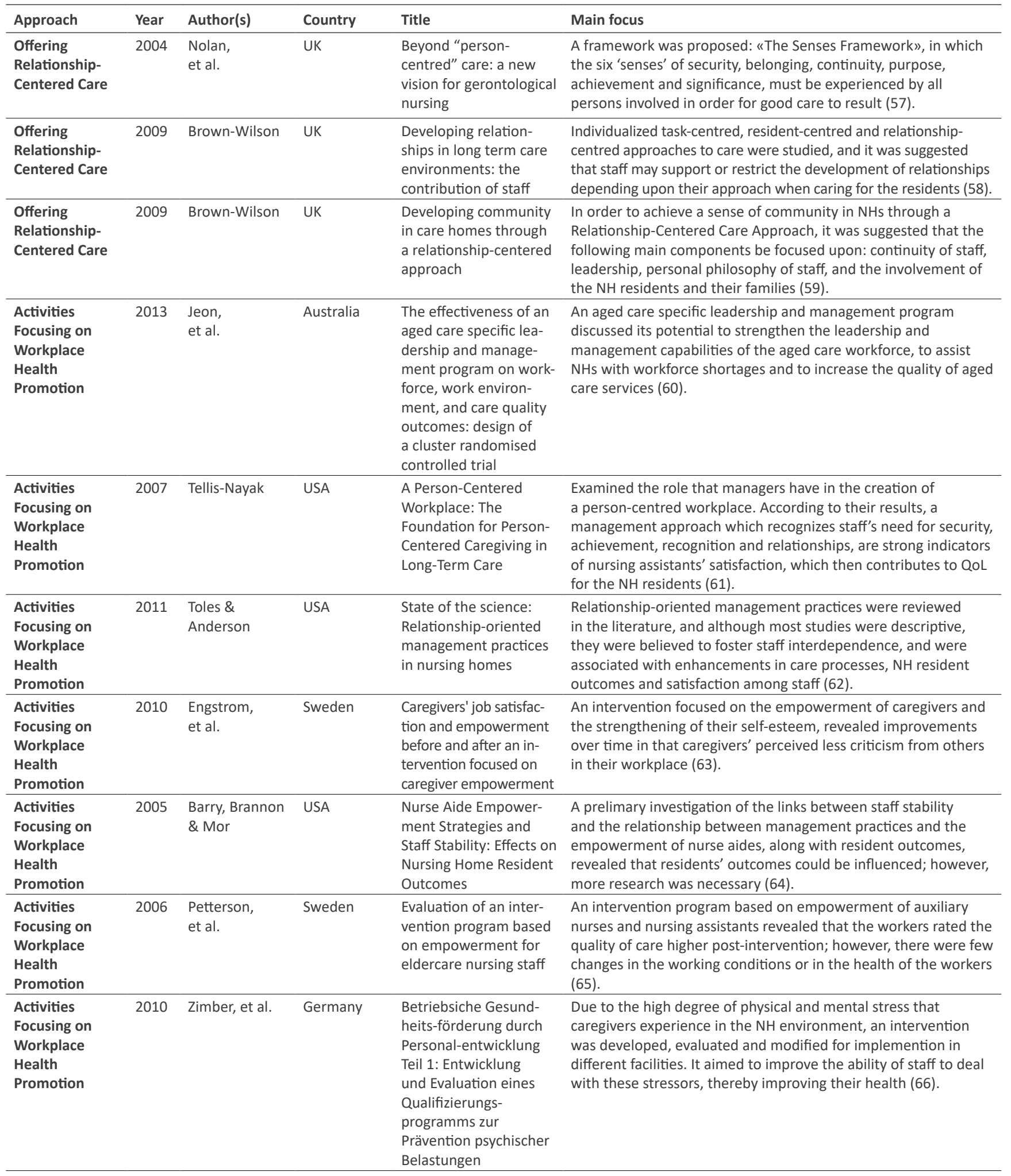


Table 3. Continued

\begin{tabular}{|c|c|c|c|c|}
\hline Approach & Year & Author(s) & Country & Title \\
\hline $\begin{array}{l}\text { Activities } \\
\text { Focusing on } \\
\text { Workplace } \\
\text { Health } \\
\text { Promotion }\end{array}$ & 2019 & $\begin{array}{l}\text { Tempelmann, } \\
\text { et al. }\end{array}$ & Germany & $\begin{array}{l}\text { Qualitätsorientierte } \\
\text { Prävention und Gesund- } \\
\text { heitsförderung in Ein- } \\
\text { richtungen der Pflege: Das } \\
\text { Projekt QualiPEP (Quality } \\
\text { prevention and health } \\
\text { promotion programming } \\
\text { in long-termcare: the } \\
\text { QualiPEP Project) }\end{array}$ \\
\hline
\end{tabular}

\begin{tabular}{|c|c|c|c|c|c|}
\hline $\begin{array}{l}\text { Activities } \\
\text { Focusing on } \\
\text { Workplace }\end{array}$ & 2005 & Rosen, et al. & USA & $\begin{array}{l}\text { Organizational } \\
\text { Change and Quality } \\
\text { Improvement in }\end{array}$ & $\begin{array}{l}\text { Only when the quality improvement process was adapted to } \\
\text { include real-time feedback, were improvements in quality } \\
\text { achieved (68). }\end{array}$ \\
\hline
\end{tabular}

Health Nursing Homes:

$\begin{array}{lll}\text { Promotion } & \text { Approaching Success }\end{array}$

Activities 2010 Gregerson, Germany Betriebliche Gesund-

Focusing on et al. heits-förderung durch

Workplace Personal-entwicklung

Health Personal-entwicklung Teil II: Praxis-transfer eines Qualifizierungsprogramms zur Prävention psychischer Belastungen

\begin{tabular}{|c|c|c|c|c|c|}
\hline $\begin{array}{l}\text { Activities } \\
\text { Focusing on } \\
\text { Workplace } \\
\text { Health } \\
\text { Promotion }\end{array}$ & 2015 & Miranda, et al. & $\begin{array}{l}\text { USA \& } \\
\text { Finland }\end{array}$ & $\begin{array}{l}\text { Health Behaviors and } \\
\text { Overweight in Nursing } \\
\text { Home Employees: } \\
\text { Contribution of Work- } \\
\text { place Stressors and Im- }\end{array}$ & $\begin{array}{l}\text { Recently, a strong association was found between workplace } \\
\text { stressors and cigarette smoking, physical inactivity and obesity. } \\
\text { Physical and organizational workplace stressors included low } \\
\text { decision making, minimal coworker support, regular night shifts, }\end{array}$ \\
\hline
\end{tabular}

Promotion place Stressors and Implications for Worksite Health Promotion

\begin{tabular}{|c|c|c|c|c|c|}
\hline $\begin{array}{l}\text { Activities } \\
\text { Focusing on } \\
\text { Workplace } \\
\text { Health } \\
\text { Promotion }\end{array}$ & 2016 & Zhang, et al. & USA & $\begin{array}{l}\text { Workplace Participa- } \\
\text { tory Occupational } \\
\text { Health/Health } \\
\text { Promotion Program - } \\
\text { Facilitators and Barriers } \\
\text { Observed in Three } \\
\text { Nursing Homes }\end{array}$ & $\begin{array}{l}\text { Facilitators and barriers influencing the effectiveness of an } \\
\text { occupational health/ HP program in three NHs, were recently } \\
\text { evaluated from both managers' and employees' views. From } \\
\text { the employees' perspectives, strong predictors of a healthy } \\
\text { work environment were leadership/ management support, } \\
\text { communication, job demands and resources (71). }\end{array}$ \\
\hline
\end{tabular}

\begin{tabular}{|c|c|c|c|c|}
\hline $\begin{array}{l}\text { Activities } \\
\text { Focusing on } \\
\text { Workplace } \\
\text { Health } \\
\text { Promotion }\end{array}$ & 2020 & Otto, et al. & Germany & $\begin{array}{l}\text { Physical activity and } \\
\text { health promotion for } \\
\text { nursing staff in elderly } \\
\text { care: a study protocol } \\
\text { for a randomised } \\
\text { controlled trial }\end{array}$ \\
\hline
\end{tabular}

\begin{tabular}{|c|c|c|c|c|c|}
\hline $\begin{array}{l}\text { Activities } \\
\text { Focusing on } \\
\text { Workplace } \\
\text { Health } \\
\text { Promotion }\end{array}$ & 2020 & Syed & Canada & $\begin{array}{l}\text { Diet, physical activity, } \\
\text { and emotional health: } \\
\text { what works, what } \\
\text { doesn't, and why } \\
\text { we need integrated } \\
\text { solutions for total } \\
\text { worker health }\end{array}$ & $\begin{array}{l}\text { This study utilized ethnography at a NH in Canada to examine } \\
\text { the health practices of health care workers from high-stress, high } \\
\text { turnover environments. } 42 \text { ind. Interviews were also conducted } \\
\text { with staff. It focused on NH staff mechanisms for maintaining } \\
\text { physical, emotional, and social wellbeing. It emphasized } \\
\text { that workplace HP and protection must be addressed at the } \\
\text { individual, organizational, and structural levels. It discusses total } \\
\text { worker health (TWH) initiatives which incorporate the social } \\
\text { determinants of health (73). }\end{array}$ \\
\hline $\begin{array}{l}\text { Activities } \\
\text { Focusing on } \\
\text { Workplace } \\
\text { Health } \\
\text { Promotion }\end{array}$ & 2020 & Kernan, et al. & USA & $\begin{array}{l}\text { A Corporate Wellness } \\
\text { Program and Nursing } \\
\text { Home Employees' } \\
\text { Health }\end{array}$ & $\begin{array}{l}\text { This non-experimental study examined the association of a com- } \\
\text { pany-sponsored workplace health program in the nursing homes } \\
\text { with workers' health indicators, health beliefs and behaviors, and } \\
\text { work environment conditions. There were no major differences } \\
\text { across the programs with respect to most outcomes (74). }\end{array}$ \\
\hline
\end{tabular}


Ottawa Charter Action Strategies and population health levels

All Ottawa Charter action strategies were focused upon in the Ecological Approach and Comprehensive Settings Approach (see Figure 3). The two Ottawa Charter action strategies of creating a supportive environment and on re-orienting health services were strongly targeted in all of the approaches. The strategy of developing personal skills was minimally to moderately focused upon in all of the approaches. Strengthening community action was very minimally utilized with four of the five approaches, except for with the Ecological Approach and Comprehensive Settings Approach, which had a strong utilization of it. Building healthy public policy was either minimally or not focused on at all within all of the approaches. Utilization of the population health levels within the broader Ottawa Charter action strategies revealed that each approach predominately focused on the levels of the NH, the sector/system as well as the societal levels.

These results demonstrated the unity of all the approaches in their targeting of the Ottawa Charter action strategies of creating a supportive environment and of re-orienting health services. Significant gaps were present in the utilization of strengthening community action and building upon healthy public policy. Another gap present was with the population health level at the family level.

\section{Social Determinants of Health}

The Social Determinant of Health of the social environment was focused upon in all of the approaches. Governance was also focused on with all of the approaches, except for with the Activities Focusing on WHP, in which there was minimal usage of it. The physical environment was also targeted upon in all of the approaches, although the Offering Relationship-Centered Care utilized it minimally. The active aging determinants were only targeted in the QoL Approach.

These results highlight that even though they did not label their focus as being on a Social Determinant of Health, they did clearly target their efforts on the social environment and on governance. Most of the approaches also focused on the physical environment. In contrast, the Active Aging Determinants were only targeted in one of the approaches.

\section{Discussion}

This paper aimed to provide an overview of the literature, in order to address the research gap of a lack of information regarding HP strategies utilized in the $\mathrm{NH}$ setting. It focuses on examining which HP approaches exist in the NH setting, along with the extent HP has been systematically applied. In this paper, conceptual overlap was present among the approaches themselves and within the concepts of HP which were discussed, as HP intersects with many other concepts in health care. Based on 64 publications, five approaches have been identified. The publications within the approaches provide valuable insight as to the wide variety of ways in which HP has already been applied in the $\mathrm{NH}$ setting, with both residents and staff. In the earlier literature, both groups were seldom united into one initative. However, in the last 4 years, this has started to become more evident $(24 ; 67)$. This is very important, as the well-being of both the residents and staff in NHs are interrelated and greatly influence one another. Additionally, it also became evident that in many of the publications, HP was neither labelled nor recognized as being a part of the study. Even though programs or interventions were being implemented which were often directly related to HP practice, there was often no mention of it being HP. This has also started to slowly change in the more recent literature (22), especially in regard to workplace $\mathrm{HP}$ initiatives for staff. It was also revealed, that program or model development and delivery has generally been fragmented and applied unsystematically in the NH setting (34). However, use of the adapted structured protocol, enabled us to identify both strengths and areas for improvement within the approaches.

Strengths of the approaches in their application of health promotion in nursing homes A major strength of the approaches is their strong focus on the Ottawa Charter action strategies of creating a supportive environment and of re-orienting health services, and is congruent with recommendations from major policy documents (75-78). The emphasis on these two action strategies clearly demonstrates the importance of changing the social and physical environment along with the accompanying policies, in order to make the transition from a medical model to a more age-friendly philosophy (e.g., the CCM). Additionally, a strength was the approaches moderate focus on developing personal skills. This was targeted, for example, with the empowerment, participation and skill building of care-workers, along with emphasis on empowering and participative leadership practices in the NH setting. Participation and empowerment are very important in HP practice when supporting individuals and groups with the development of their skills, as well as when promoting a healthy workplace. 
Ottawa Charter Action Strategies \& at what leve

1-Individual Level; 2-Family Level; 3-Community Level (Nursing Home); 4-Sector/System Level; 5-Societal Level

Evidence of SDOH?

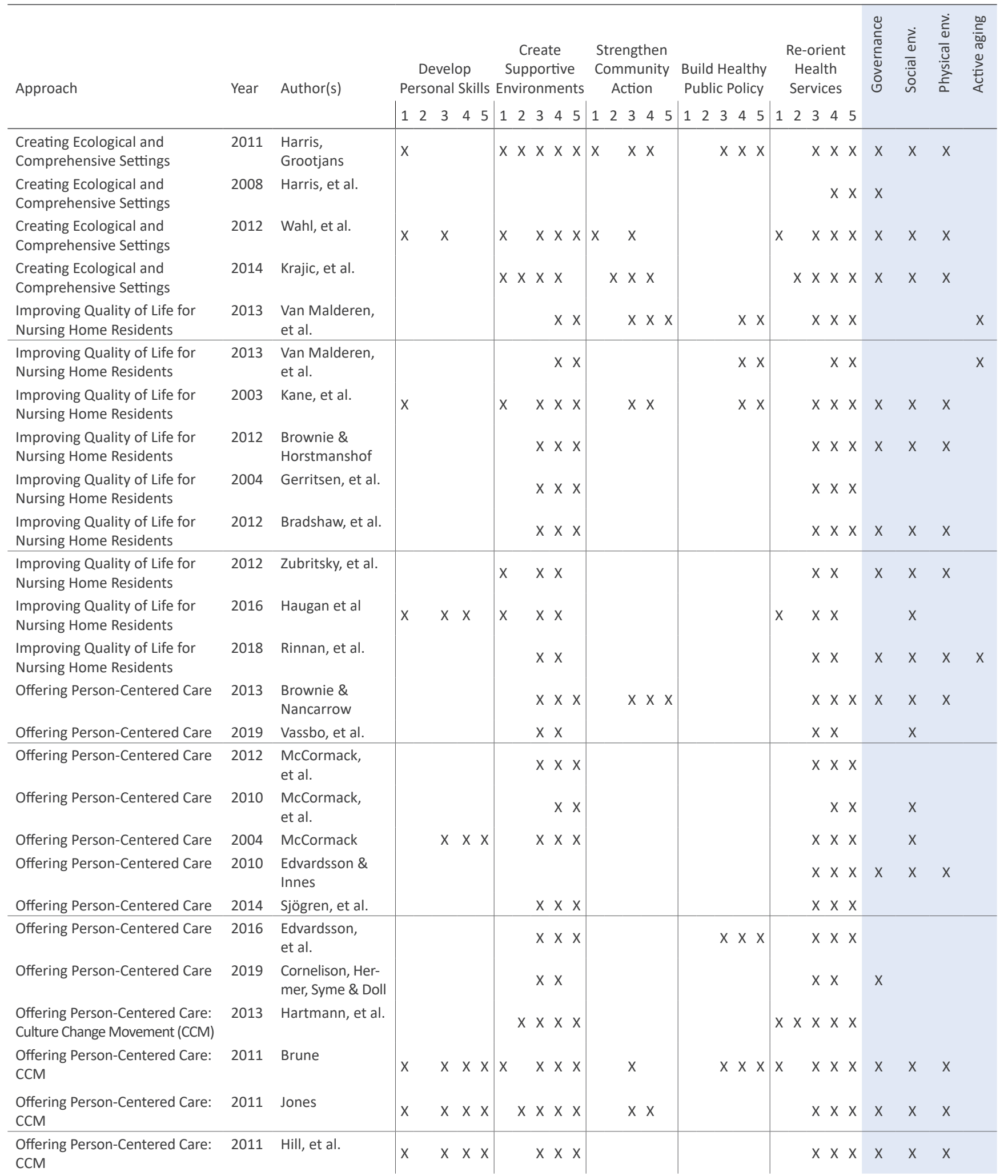

Figure 3. Continues 


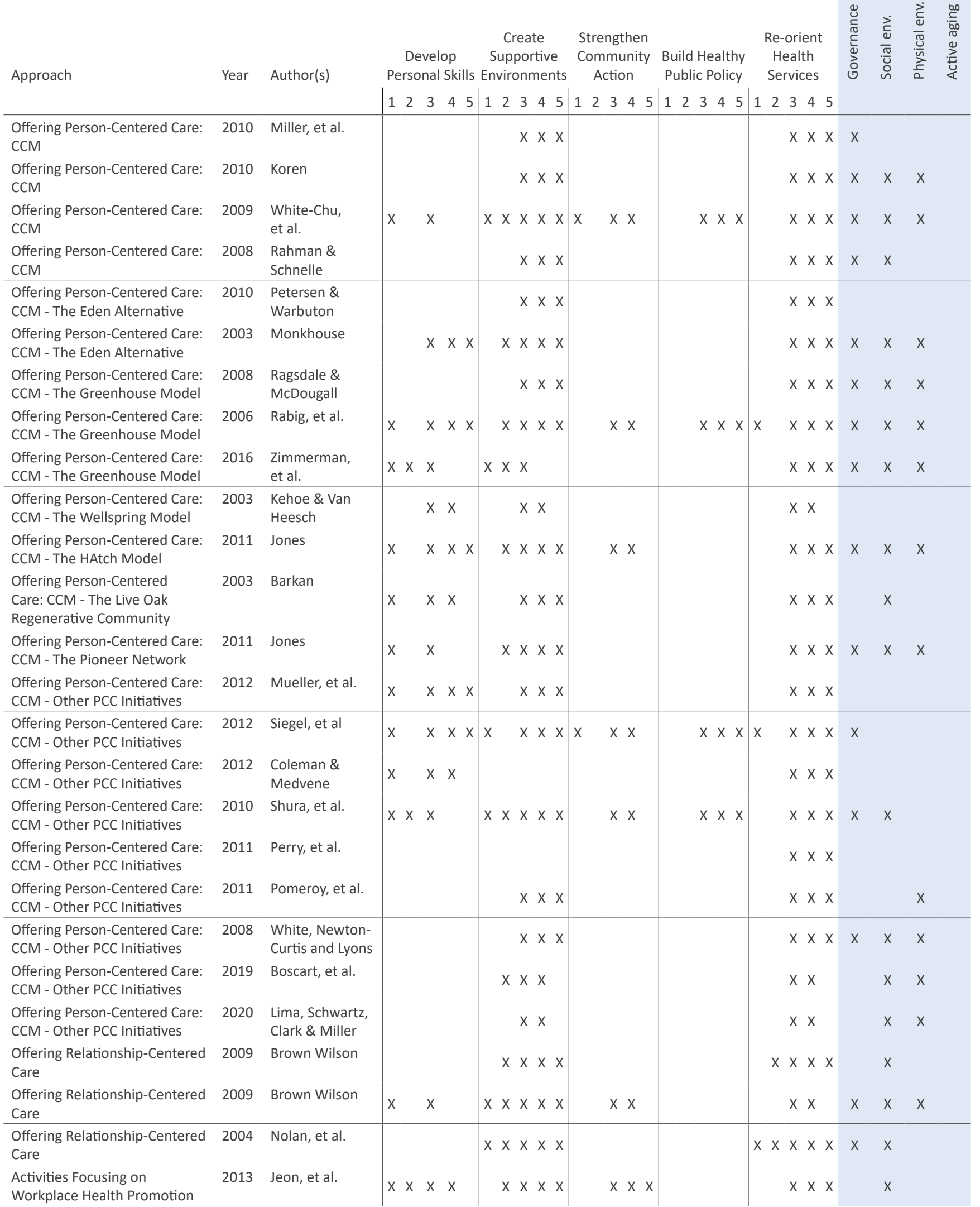




\section{Research and Best Practice}

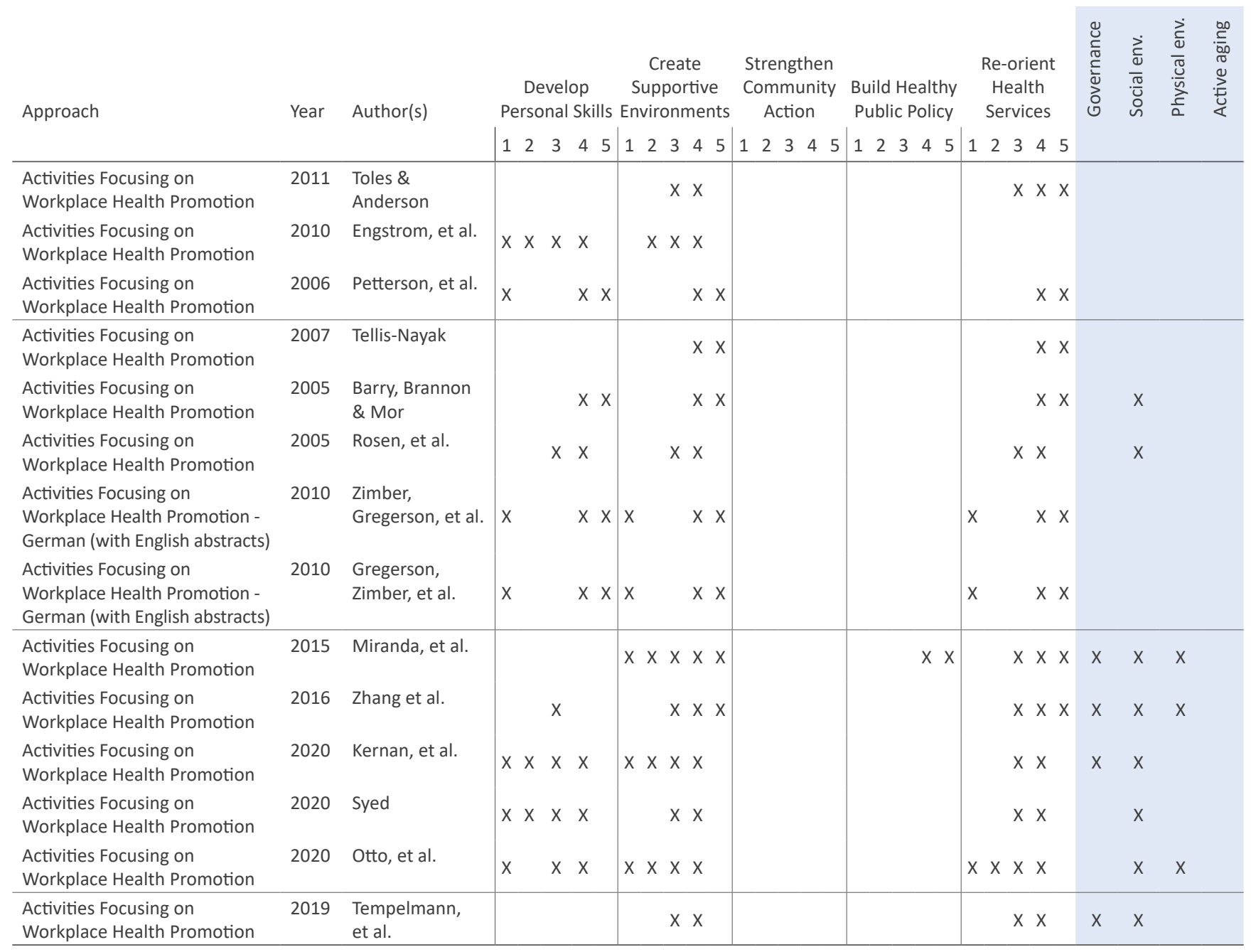

Figure 3. Summary and categorization of included articles

The population health levels were predominately focused on at the sector/system and the societal levels. For example, with the Offering of Person-Centered Care, the multiple models and ideas have slowly progressed as a movement aiming for improvements in NHs at national levels. The very strong focus on the Social Determinants of Health of the social environment, governance, as well as the physical environment, indicate the important influence and significance that they have in improving the well-being of the residents and staff. Residents spend the vast majority of their time in the NH environment and their well-being is greatly affected by their social and physical environment, along with the governing policies of the NH. Therefore, $\mathrm{NH}$ residents are very vulnerable to any deficits in these areas. Staff are also vulnerable to them, as it is the policies of NHs which influence their daily operations and work culture.
Areas for improvement of the approaches in their application of health promotion in nursing homes

Significant areas for improvement among the approaches were, however, present in the utilization of two Ottawa Charter action strategies: strengthening community action and building upon healthy public policy. There was very little planning or acknowledgement given to the importance of integration of the $\mathrm{NH}$ with its surrounding community, citizens, and other generations (e.g. sharing of community gardens with NHs, activities for the very young and the very old together, suitable sidewalks and transportation for older persons). NHs targeting their efforts towards the formation of close-relationships are likely to make positive differences in the the social integration, social connectedness, and health outcomes of $\mathrm{NH}$ residents, and also thereby improve the quality of care being delivered 
(22;79). Utilization of existing frameworks which have been designed for the NH setting, such as those focusing on meaningful leisure and participation (9), could assist in increasing residents' social inclusion with their surrounding communities.

A further area for improvement with three of the approaches, was with actions directed at the population health level of family. This lack of focus indicates that although much has been done in recent years, involvement and integration of the family is still not very visible in the $\mathrm{NH}$ setting. Especially when aiming to promote residents' well-being, the establishment of close relationships with residents' family members is very important (79).

One of the Social Determinants of Health, the active aging determinants, was only targeted in one approach. This is likely because it was designed for older persons in the community setting, and has only been recently proposed as being applicable to older persons in the NH setting (9). As recommended, activities which promote meaningful leisure and participation are especially important for NH residents (9), and could occur through participation with their surrounding community. The promotion of activities which are decided upon by the residents, could for example, be an easy-to-implement action.

\section{Strengths and limitations}

This scoping review focused on the analysis of approaches in the NH setting, utilizing a structured protocol, which allowed for extraction, documentation and synthesis of the data. To our knowledge, such a synthesis of systematic HP in the $\mathrm{NH}$ setting has not been done before, and it provided a unique lens through which to view the current situation. A major strength of this study is that it offers a comprehensive and systematic synthesis of the ways and extent in which HP has been applied. It considers both staff and residents, which is crucial, as they greatly influence one another, and should therefore be viewed together.

A limitation of this paper is that the Social Determinants of Health that apply specifically to residents in NHs are unknown; therefore, the Integrated Model of Population Health and HP framework had to be adapted. Another limitation is that, due to the study's broad focus and chosen methodology, this paper serves as an overview. Less focus was placed on the quality of the included publications, and expert opinions and pilot projects were also included, in order to provide an comprehensive overview of the literature. Additionally, it included English publications and those in German with English abstracts, which could be viewed as a potential limitation.

\section{Challenges specific to the nursing home setting} The underlying aim of the five main approaches which were extracted from this study, was to improve the living conditions for $\mathrm{NH}$ residents and/or the working conditions for staff. It is well-known that the working conditions in NHs are sub-optimal due to staff shortages, inadequate levels of registered nurses, high workload, and a high rate of dementia among the residents (80), along with staff retention and turnover issues (81). Older persons are frequently afflicted with chronic diseases and cognitive challenges, which can trigger admission to a $\mathrm{NH}$ (4). Staff must have adequate medical knowledge, along with expertise, regarding how to best care for residents with such health challenges in order to provide optimal care. Working in a NH setting is considered by some staff to be more stressful than in the acute care setting (5).

Other challenges are also prevalent in the NH setting. Front-line workers such as certified nursing assistants and other care-aides, consist of over half of the workforce (70). Issues present for care-workers in the $\mathrm{NH}$ environment include heavy workload, psychological stress due to high demand and low control (73;74), being undervalued by management and a shortage of necessary resources (82). Health problems such as poor mental health, musculoskeletal dysfunctions along with cardiovascular disease, can then occur (71). These issues also contribute to the well-documented high turnover rate (71). The factors most associated with strong job satisfaction in Swiss NH care-workers were reported as: "NH leadership, teamwork and safety climate, the resonance of the $\mathrm{NH}$ administrator, workers' perceptions of staffing adequacy, (less) workplace conflicts and (fewer) health complaints" (83). Leadership at both the supervisor and executive administrator level was viewed as being the most important factor for job satisfaction (83).

Registered nurses along with team/middle managers also face particular challenges in the nursing home environment. Besides the medical knowledge necessary to care for complex residents, the following themes an expert nurse requires in the NH setting were proposed as: context of the $\mathrm{NH}$, knowing the $\mathrm{NH}$ resident, transitions, moral agency, saliency, holistic knowledge, and skills/know-how (84). Further, due to the effect management has on employees' health and well-being, leadership development is viewed as being especially important in NHs (71). Leadership style along with supportive management, through increasing care-wor- 
ker participation, empowerment, and influence, can increase the quality of care that is provided to residents (85).

The studies analysed, in general, did not direct their focus on the discussion of these challenges; rather they were mostly focused on strategies to alleviate them. However, it is important to place emphasis on these challenges when examining how HP could be systematically utilized, in order to improve the living conditions for NH residents and the working conditions for staff. Many aspects of a medical model remain vital in ensuring that residents' often complex physical and psychological requirements can be met. Strong leadership is also necessary to support the team in the meeting of residents' needs.

\section{Why health promotion in the nursing home set- ting... and how?}

As discussed in the previous section, there are many issues present in NHs. HP practice often focuses on the workplace setting, and as such, can have a major impact upon the workers' well-being (14). This study reveals that a variety of approaches and practices do exist which at least partially apply $\mathrm{HP}$ in the $\mathrm{NH}$ setting, and that more recognition is recently being given to HP for both residents and staff. For example, in the past five years in Germany, a federal directive has been given to develop a quality concept focusing on improving the effectiveness and sustainability of HP and prevention in long-term care settings (67). Some Workplace HP programs are also tackling the complexity of the NH setting, by moving beyond behavioral changes with the staff, to integrating organizational-level changes $(73 ; 74)$. Evaluation has also recently become more evident in the research, as with the first national US study assessing the adoption of Culture Change in NHs (37). More specific implementation evaluation has also occurred with Person-Centered Care approach (36). However, with the exception of some recent advancements as well as examples in the Offering Person-Centered Care, many initiatives are lacking a systematic approach. This is especially evident in regard to the systematic application of HP. Therefore, an important research implication regarding these findings, is that more studies are necessary which focus on the implementation and evaluation of systematic HP approaches in NHs.

In order to promote more sustainable and efficient use of resources among NHs, we recommend the development of a framework depicting how to systematically utilize $\mathrm{HP}$ in the NH setting. It is important that the Ottawa Charter action strategies and the Social Determinants of Health be components in this framework, as they are key to the comprehensive and systematic guiding of HP practice. The development of such a HP framework for the NH setting could be supported by examples of HP initiatives which already exist in other settings (e.g. health promoting schools, health promoting hospitals, etc.) (86). Additionally, our study identified that the Ecological Settings Approach has been specifically applied to the NH setting via the development of a framework (7). In Austria, a comprehensive HP pilot project was also implemented (5). Additionally, the WHO Active Aging Determinants offer valuable recommendations for the NH setting (9). These resources, together with initiatives from other settings, could assist in the development of a framework focusing on the implemention of systematic HP specifically for NHs.

\section{Conclusions}

Complementary approaches which meet the needs of both the residents and the nursing staff are needed in NHs. This scoping review provided a new way of viewing HP in the NH setting. Through the systematic use of key HP concepts (a combination of the Ottawa Charter action strategies, the targeted Population Health Levels and the Social Determinants of Health), it was revealed how HP has most often been applied in NHs. It is now more apparent where progress has been made and where gaps still exist, in the implementation of HP in this setting. As an additional step, it is proposed that HP be used more systematically in order to continue to improve the well-being for both the residents and the staff in NHs. Importantly, HP is ideal for connecting resources and settings together, for example, by linking NHs together and facilitating in the sharing of resources and knowledge within a city or a region. At local levels as well as at national and international levels, more sustainable and effective ways of delivering care in the NH setting are needed, especially with the ever-increasing number of older persons in society. Systematically applied HP offers much potiential for improving the well-being of both residents and staff, and could greatly contribute to the ongoing progress being made in this setting.

\section{Acknowledgements}

Financial support from the Bern University of Applied Sciences, Department of Health Professions, Applied Research \& Development in Nursing, is kindly acknowledged.

\section{Contributors:}

Conception and design of the study: TH, KS. Acquisition of data: TH, KS. Analysis and interpretation data: TH, KS, SH. Drafting the article: TH, KS, SH, JMGAS. Revisions and final approval of the article: TH, KS, SH, JMGAS. 
Competing interests: None declared.

Funding: This research was financed by the Bern University of Applied Sciences, Department of Health Professions, Division of Nursing, Switzerland.

Patient content: Not applicable.

Ethics approval: Not applicable.

Availability of data and materials: All data generated or analysed during this study are included in this published article.

\section{References}

(1) Katz PR. An International Perspective on Long Term Care: Focus on Nursing Homes. J Am Med Dir Assoc. 2011;12:487-492.e1. doi:10.1016/j.jamda.2011.01.017.

(2) Kane RL, Rockwood T, Hyer K, et al. Rating the Importance of Nursing Home Residents' Quality of Life. J Am Geriatr Soc. 2005;53:2076-82. doi:10.1111/j.1532-5415.2005.00493.x.

(3) Brownie S, Horstmanshof L. Creating the Conditions for Self-Fulfilment for Aged Care Residents. Nurs Ethics. 2012;19:777-86. doi:10.1177/0969733011423292.

(4) Abumaria IM, Hastings-Tolsma M, Sakraida TJ. Levine's Conservation Model: A Framework for Advanced Gerontology Nursing Practice. Nurs Forum. 2015;50:179-88. doi:10.1111/nuf.12077.

(5) Krajic K, Cichocki M, Quehenberger V. Health-Promoting Residential Aged Care: A Pilot Project in Austria. Health Promot Int. 2015;30:769-81. doi:10.1093/heapro/dau012.

(6) Government of Canada. Ottawa Charter for Health Promotion: An International Conference on Health Promotion 2012.09.14. [Available from: https://www.canada.ca/en/public-health/services/health-promotion/population-health/ottawa-charter-health-promotion-international-conference-on-health-promotion.html].

(7) Harris N, Grootjans J. The Application of Ecological Thinking to Better Understand the Needs of Communities of Older People. Australas J Ageing. 2012;31:17-21. doi:10.1111/j.1741-6612.2010.00501.x

(8) WHO. Active Ageing: A Policy Framework. 2002. [Available from: $\underline{\mathrm{htt}}$ ps://www.who.int/ageing/publications/active ageing/en/].

(9) Van Malderen L, Mets T, De Vriendt P, Gorus E. The Active AgeingConcept Translated to the Residential Long-Term Care. Qual Life Res. 2013;22:929-37. doi:10.1007/s11136-012-0216-5.

(10) Arksey H, O'Malley L. Scoping Studies: Towards a Methodological Framework. Int. J. Soc. Res. Methodol. 2005;8:19-32. doi:10.1080/13645570 $\underline{32000119616 .}$.

(11) Levac D, Colquhoun H, O'Brien K. Scoping studies: advancing the methodology. Implement Sci. 2010;5:69. doi:10.1186/1748-5908-5-69.

(12) The Joanna Briggs Institute. The Joanna Briggs Institute Reviewers' Manual 2015 Methodology for JBI Scoping Reviews. The University of Adelaide, South Australia: The Joanna Briggs Institute 2015.

(13) Moher D, Liberati A, Tetzlaff J, Altman DG, PRISMA Group. Preferred Reporting Items for Systematic Reviews and Meta-Analyses: The PRISMA Statement. PLoS Med. 2009;6:e1000097. doi:10.1371/journal. pmed.1000097.

(14) Public Health Agency of Canada. Population Health Promotion: An Integrated Model of Population Health and Health Promotion. 1996. [Available from: https://www.canada.ca/en/public-health/services/health-promotion/population-health/population-health-promotion-integrated-model-population-health-health-promotion.html].

(15) Harris N, Grootjans J, Wenham K. Ecological Aging: The Settings Approach in Aged Living and Care Accommodation. EcoHealth. 2008;5:196-204. doi:10.1007/s10393-008-0176-y.

(16) Wahl H-W, Iwarsson S, Oswald F. Aging Well and the Environment: Toward an Integrative Model and Research Agenda for the Future. Gerontologist. 2012;52:306-16. doi:10.1093/geront/gnr154.

(17) Bradshaw SA, Playfore ED, Riazi A. Living Well in Care Homes: A Systematic Review of Qualitative Studies. Age Ageing. 2012;41:429-40. doi:10.1093/ageing/afs069.

(18) Kane RA, Kling KC, Bershadsky B, et al. Quality of Life Measures for
Nursing Home Residents. J Gerontol A Biol Sci Med Sci. 2003;58:240-8. doi:10.1093/gerona/58.3.m240.

(19) Gerritsen DL, Steverink N, Ooms ME, Ribbe MW. Finding a Useful Conceptual Basis for Enhancing the Quality of Life of Nursing Home Residents. Qual Life Res. 2004;13:611-24. doi:10.1023/B:QURE.0000021314.17605.40. (20) Van Malderen L, Mets T, Gorus E. Interventions to Enhance the Quality of Life of Older People in Residential Long-Term Care: A Systematic Review. Ageing Res Rev. 2013;12:141-50. doi:10.1016/i.arr.2012.03.007.

(21) Zubritsky C, Abbott KM, Hirschman KB, Bowles KH, Foust JB, Naylor MD. Health-Related Quality of Life: Expanding a Conceptual Framework to Include Older Adults Who Receive Long-Term Services and Supports. Gerontologist. 2013;53:205-10. doi:10.1093/geront/gns093.

(22) Rinnan E, Andre B, Drageset J, Garasen H, Espnes GA, Haugan G. Joy of Life in Nursing Homes: A Qualitative Study of What Constitutes the Essence of Joy of Life in Elderly Individuals Living in Norwegian Nursing Homes. Scand J Caring Sci. 2018;32:1468-76. doi:10.1111/scs.12598.

(23) Haugan G, Moksnes UK, Lohre A. Intrapersonal Self-Transcendence, Meaning-in-Life and Nurse-Patient Interaction: Powerful Assets for Quality of Life in Cognitively Intact Nursing-Home Patients. Scand J Caring Sci. 2016;30:790-801. doi:10.1111/scs.12307.

(24) Vassb $\varnothing$ TK, Kirkevold M, Edvardsson D, Sjögren K, Lood Q, Bergland $\AA$. The Meaning of Working in a Person-Centred Way in Nursing Homes: A Phenomenological-Hermeneutical Study. BMC Nurs. 2019;18:45. doi:10.1186/s12912-019-0372-9.

(25) McCormack B, Roberts T, Meyer J, Morgan D, Boscart V. Appreciating the 'Person' in Long-Term Care. Int J Older People Nurs. 2012;7:284-94. doi:10.1111/i.1748-3743.2012.00342.x.

(26) McCormack B. Person-Centredness in Gerontological Nursing: An Overview of the Literature. J Clin Nurs. 2004;13:31-8. doi:10.1111/i.13652702.2004.00924.x.

(27) McCormack B, Dewing J, Breslin L, et al. Developing Person-Centred Practice: Nursing Outcomes Arising From Changes to the Care Environment in Residential Settings for Older People. Int J Older People Nurs. 2010;5:93107. doi:10.1111/j.1748-3743.2010.00216.x.

(28) Boscart VM, Sidani S, Ploeg J, et al. Neighbourhood Team Development to Promote Resident Centred Approaches in Nursing Homes: A Protocol for a Multi Component Intervention. BMC Health Serv Res. 2019;19:922. doi:10.1186/s12913-019-4747-0.

(29) Sjogren K, Lindkvist M, Sandman PO, Zingmark K, Edvardsson D. To What Extent Is the Work Environment of Staff Related to Person-Centred Care? a Cross-Sectional Study of Residential Aged Care. J Clin Nurs. 2014;24:1310-9. doi:10.1111/jocn.12734.

(30) Siegel EO. Supporting and Promoting Personhood in Long Term Care Settings: Contextual Factors. Int J Older People Nurs. 2012;7:295-302. doi:10.1111/opn.12009.

(31) Mueller C, Burger S, Rader J, Carter D. Nurse Competencies for Person-Directed Care in Nursing Homes. Geriatr Nurs. 2012;34:101-4. doi:10.1016/i.gerinurse.2012.09.009.

(32) Coleman CK, Medvene LJ, Van Haitsma K. A Person-Centered Care Intervention for Geriatric Certified Nursing Assistants. Gerontologist. 2013;53:687-98. doi:10.1093/geront/gns135.

(33) Shura R, Siders RA, Dannefer D. Culture Change in Long-Term Care: Participatory Action Research and the Role of the Resident. Gerontologist. 2011;51:212-25. doi:10.1093/geront/gnq099.

(34) Perry L, Bellchambers H, Howie A, et al. Examination of the Utility of the Promoting Action on Research Implementation in Health Services Framework for Implementation of Evidence Based Practice in Residential Aged Care Settings. J Adv Nurs. 2011;67:2139-50. doi:10.1111/i.13652648.2011.05655.x.

(35) Brownie S, Nancarrow S. Effects of Person-Centered Care on Residents and Staff in Aged-Care Facilities: A Systematic Review. Clin Interv Aging. 2013;8:1-10. doi:10.2147/CIA.S38589.

(36) Cornelison LJ, Hermer L, Syme ML, Doll G. Initiating Aha Moments When Implementing Person-Centered Care in Nursing Homes: A Multi-Arm, Pre-Post Intervention. BMC Geriatr. 2019;19:115. doi:10.1186/ s12877-019-1121-3.

(37) Lima JC, Schwartz ML, Clark MA, Miller SC. The Changing Adop- 
tion of Culture Change Practices in U.S. Nursing Homes. Innov Aging. 2020;4:igaa012. doi:10.1093/geroni/igaa012.

(38) Edvardsson D, Backman A, Bergland Å, et al. The Umeå Ageing and Health Research Programme (U-Age): Exploring Person-Centred Care and Health-Promoting Living Conditions for an Ageing Population. Nord J Nurs Res. 2016;36:168-74. doi:10.1177/2057158516645705.

(39) White DL, Newton-Curtis L, Lyons KS. Development and Initial Testing of a Measure of Person-Directed Care. Gerontologist. 2008;48:114-23. doi:10.1093/geront/48.supplement 1.114.

(40) Edvardsson D, Innes A. Measuring Person-Centered Care: A Critical Comparative Review of Published Tools. Gerontologist. 2010;50:834-46. doi:10.1093/geront/gnq047.

(41) Pomeroy SH, Scherer Y, Runkawatt V, lamsumang W, Lindemann J, Resnick B. Person-Environment Fit and Functioning Among Older Adults in a Long-Term Care Setting. Geriatr Nurs. 2011;32:368-78. doi: 10.1016/j.gerinurse.2011.07.002.

(42) Brune K. Culture Change in Long Term Care Services: Eden-Greenhouse-Aging in the Community. Educ Gerontol. 2011;37:506-25. doi:10.1080/ 03601277.2011.570206.

(43) Hartmann CW, Snow AL, Allen RS, Parmelee PA, Palmer JA, Berlowitz D. A Conceptual Model for Culture Change Evaluation in Nursing Homes. Geriatr Nurs. 2013;34:388-94. doi:10.1016/j.gerinurse.2013.05.008.

(44) White-Chu EF, Graves WJ, Godfrey SM, Bonner A, Sloane P. Beyond the Medical Model: The Culture Change Revolution in Long-Term Care. J Am Med Dir Assoc. 2009;10:370-8. doi:10.1016/j.jamda.2009.04.004.

(45) Rahman AN, Schnelle JF. The Nursing Home Culture-Change Movement: Recent Past, Present, and Future Directions for Research. Gerontologist. 2008;48:142-8. doi:10.1093/geront/48.2.142.

(46) Hill NL, Kolanowski AM, Milone-Nuzzo P, Yevchak A. Culture Change Models and Resident Health Outcomes in Long-Term Care. J Nurs Scholarsh. 2011;43:30-40. doi:10.1111/j.1547-5069.2010.01379.x.

(47) Miller SC, Miller EA, Jung HY, Sterns S, Clark M, Mor V. Nursing Home Organizational Change: The "Culture Change" Movement as Viewed by Long-Term Care Specialists. Med Care Res Rev. 2010;67:65S-81S. doi:10.1177/1077558710366862.

(48) Koren MJ. Person-Centered Care for Nursing Home Residents: The Culture-Change Movement. Health Aff (Millwood). 2010;29:312-7. doi:10.1377/hlthaff.2009.0966.

(49) Jones CS. Person-Centered Care. The Heart of Culture Change. J Gerontol Nurs. 2011;37:18-23. doi:10.3928/00989134-20110302-04.

(50) Petersen M, Warbuton J. The Eden Model: Innovation in Australian Aged Care? Australas J Ageing. 2010;29:126-9. doi:10.1111/i.17416612.2010.00419.x.

(51) Monkhouse C. Beyond the Medical Model - the Eden Alternative in Practice: A Swiss Experience. Journal of Social Work in Long-Term Care. 2003;2:339-53. doi:10.1300/J181v02n03 11.

(52) Ragsdale V, McDougall GJ, Jr. The Changing Face of Long-Term Care: Looking at the Past Decade. Issues Ment Health Nurs. 2008;29:992-1001. doi:10.1080/01612840802274818.

(53) Zimmerman S, Bowers BJ, Cohen LW, Grabowski DC, Horn SD, Kemper P. New Evidence on the Green House Model of Nursing Home Care: Synthesis of Findings and Implications for Policy, Practice, and Research. Health Serv Res. 2016;51:475-96. doi:10.1111/1475-6773.12430.

(54) Rabig J, Thomas W, Kane RA, Cutler LJ, McAlilly S. Radical Redesign of Nursing Homes: Applying the Green House Concept in Tupelo, Mississippi. Gerontologist. 2006;46:533-9. doi:10.1093/geront/46.4.533.

(55) Kehoe MA, Van Heesch B. Culture Change in Long Term Care: The Wellspring Model. Journal of Social Work in Long-Term Care. 2003;2:15973. doi:org/10.1300/J181v02n01 11.

(56) Barkan B. The Live Oak Regenerative Community: Championing a Culture of Hope and Meaning. Journal of Social Work in Long-Term Care. 2003;2:197-221. doi:10.1300/J181v02n01 14.

(57) Nolan MR, Davies S, Brown J, Keady J, Nolan J. Beyond Person-Centred Care: A New Vision for Gerontological Nursing. J Clin Nurs. 2004;13:45-53. doi: 10.1111/i.1365-2702.2004.00926.x.

(58) Wilson CB, Davies S. Developing Relationships in Long Term Care Environments: The Contribution of Staff. J Clin Nurs. 2008;18:1746-55. doi:10.1111/i.1365-2702.2008.02748.x.

(59) Wilson CB. Developing Community in Care Homes Through a Relationship-Centred Approach. Health Soc Care Community. 2009;17:177-86. doi:10.1111/i.1365-2524.2008.00815.x.

(60) Jeon YH, Simpson JM, Chenoweth L, Cunich M, Kendig H. The Effectiveness of an Aged Care Specific Leadership and Management Program on Workforce, Work Environment, and Care Quality Outcomes: Design of a Cluster Randomised Controlled Trial. Implement Sci. 2013;8:126. doi:10.1186/1748-5908-8-126.

(61) Tellis-Nayak V. A Person-Centered Workplace: The Foundation for Person-Centered Caregiving in Long-Term Care. J Am Med Dir Assoc. 2007;8:46-54. doi:10.1016/j.jamda.2006.09.009.

(62) Toles M, Anderson RA. State of the Science: Relationship-Oriented Management Practices in Nursing Homes. Nurs Outlook. 2011;59:221-7. doi:10.1016/j.outlook.2011.05.001.

(63) Engström M, Wadensten B, Häggström E. Caregivers' Job Satisfaction and Empowerment Before and After an Intervention Focused on Caregiver Empowerment. J Nurs Manag. 2010;18:14-23. doi:10.1111/j.13652834.2009.01047.x.

(64) Barry T, Brannon D, Mor V. Nurse Aide Empowerment Strategies and Staff Stability: Effects on Nursing Home Resident Outcomes. Gerontologist. 2005;45:309-17. doi:10.1093/geront/45.3.309.

(65) Petterson IL, Donnersvärd HÅ, Lagerström M, Toomingas A. Evaluation of an Intervention Programme Based on Empowerment for Eldercare Nursing Staff. Work \& Stress. 2006;20:353-69. doi:10.1080/02678370601070489.

(66) Zimber A, Gregersen S, Kuhnert S, Nienhaus A. Betriebliche Gesundheitsförderung durch Personalentwicklung Teil I: Entwicklung und Evaluation eines Qualifizierungsprogramms zur Prävention psychischer Belastungen. Gesundheitswesen. 2010;72:209-15. doi: 10.1055/s-0029-1214403.

(67) Tempelmann A, Kolpatzik K, Ehrenreich H, Stroing M, Hans C. Quality Prevention and Health Promotion Programming in Long-Termcare: The Qualipep Project. Bundesgesundheitsblatt-Gesund. 2019;62:296-303. doi: 10.1007/s00103-019-02910-4.

(68) Rosen J, Mittal V, Degenholtz H, et al. Organizational Change and Quality Improvement in Nursing Homes: Approaching Success. J Healthc Qual. 2005;27:6-14. doi: 10.1111/i.1945-1474.2005.tb00583.x.

(69) Gregersen S, Zimber A, Kuhnert S, Nienhaus A. Betriebliche Gesundheitsförderung durch Personalentwicklung Teil II: Praxistransfer eines Qualifizierungsprogramms zur Prävention psychischer Belastungen. Gesundheitswesen. 2010;72:216-21. doi:10.1055/s-0029-1215559.

(70) Miranda H, Gore RJ, Boyer J, Nobrega S, Punnett L. Health Behaviors and Overweight in Nursing Home Employees: Contribution of Workplace Stressors and Implications for Worksite Health Promotion. ScientificWorldJournal. 2015. doi:10.1155/2015/915359.

(71) Zhang Y, Flum M, Kotejoshyer R, Fleishman J, Henning R, Punnett L. Workplace Participatory Occupational Health/Health Promotion Program: Facilitators and Barriers Observed in Three Nursing Homes. J Gerontol Nurs. 2016;42:34-42. doi: 10.3928/00989134-20160308-03.

(72) Otto AK, Pietschmann J, Appelles LM, et al. Physical Activity and Health Promotion for Nursing Staff in Elderly Care: A Study Protocol for a Randomised Controlled Trial. BMJ Open. 2020;10:e038202. doi:10.1136/ bmjopen-2020-038202.

(73) Syed IUB. Diet, Physical Activity, and Emotional Health: What Works, What Doesn't, and Why We Need Integrated Solutions for Total Worker Health. BMC Public Health. 2020;20:152. doi: 10.1186/s12889-020-8288-6. (74) Kernan G, Cifuentes M, Gore R, Kriebel D, Punnett L. A Corporate WelIness Program and Nursing Home Employees' Health. Front Public Health. 2020;8 :531116. doi:10.3389/fpubh.2020.531116.

(75) WHO. Governance for health in the 21st century. 2012. [Available from: https://www.euro.who.int/en/publications/abstracts/governancefor-health-in-the-21st-century].

(76) WHO. Strategy and action plan for healthy ageing in Europe, 20122020. 2012. Report No.: EUR/RC62/10 Rev.1 Sixty-second session + EUR/ RC62/Conf.Doc./4 Malta, 10-13 September 2012.

(77) WHO. Health 2020: a European policy framework supporting action across government and society for health and well-being. 2013.

(78) United Nations - Principles for Older Persons, Stat. Adopted by General 


\section{Research and Best Practice}

Assembly resolution 46/91 (16 December 1991, 1991). [Available from: https://www.ohchr.org/EN/Professionallnterest/Pages/OlderPersons.aspx]. (79) Leedahl SN, Chapin RK, Little TD. Multilevel Examination of Facility Characteristics, Social Integration, and Health for Older Adults Living in Nursing Homes. J Gerontol B Psychol Sci Soc Sci. 2015;70:111-22. doi: 10.1093/geronb/gbu112.

(80) Zuniga F, Ausserhofer D, Hamers JP, Engberg S, Simon M, Schwendimann R. Are Staffing, Work Environment, Work Stressors, and Rationing of Care Related to Care Workers' Perception of Quality of Care? a Cross-Sectional Study. J Am Med Dir Assoc. 2015;16:860-6. doi: 10.1016/i.jamda.2015.04.012.

(81) Zhang Y, Punnett L, Gore R, CPH-NEW Research Team. Relationships Among Employees' Working Conditions, Mental Health, and Intention to Leave in Nursing Homes. J Appl Gerontol. 2014;33:6-23. doi: 10.1177/0733464812443085.

(82) Zhang Y, Flum M, Nobrega S, Blais L, Qamili S, Punnett L. Work Organization and Health Issues in Long-Term Care Centers - Comparison of Perceptions Between Caregivers and Management. J Gerontol Nurs. 2011;37:32-40. doi:10.3928/00989134-20110106-01.

(83) Schwendimann R, Dhaini S, Ausserhofer D, Engberg S, Zuniga F. Factors Associated With High Job Satisfaction Among Care Workers in Swiss Nursing Homes - a Cross Sectional Survey Study. BMC Nurs. 2016;15:37. doi:10.1186/s12912-016-0160-8.

(84) Phelan A, McCormack B. Exploring Nursing Expertise in Residential Care for Older People: A Mixed Method Study. J Adv Nurs. 2016;72:252435. doi:10.1111/ian.13001.

(85) Andre B, Sjøvold E, Rannestad T, Ringdal GI. The Impact of Work Culture on Quality of Care in Nursing Homes - a Review Study. Scand J Caring Sci. 2014;28:449-57. doi:10.1111/scs.12086.

(86) WHO. World report on Ageing and Health. Geneva, Switzerland: World Health Organization 2015. Contract No.: ISBN 9789240694811 (PDF). 